\title{
ČIMBENICI OTPORNOSTI I ISKUSTVO VRŠNJAČKOG NASILJA
}

\section{RESILIENCE FACTORS AND EXPERIENCE OF PEER VIOLENCE}

\author{
MATEA BELOŠEVIĆ, MARTINA FERIĆ, IVANA MITRIĆ \\ Department of Behavioural Disorders, Faculty of Education and Rehabilitation Sciences, University of Zagreb, \\ University Campus Borongaj, Zagreb, Croatia, contact: matea.belosevic@erf.unizg.hr
}

Primljeno/Received: 03.12.2021.

Prihvaćeno/Accepted: 14.07.2021

Sažetak: Svrha je ovog rada utvrditi doprinos čimbenika otpornosti u objašnjenju doživljenog vršnjačkog nasilja kao temelju planiranja znanstveno utemeljenih intervencija za promociju pozitivnog razvoja/prevenciju rizičnih ponašanja mladih. Istraživanje je provedeno na uzorku od 1647 adolescenata iz Varaždinske županije, a raspon dobi kreće se od 14 do 19 godina. Za potrebe ovog rada korišten je Upitnik o demografskim podacima (izrađen za potrebe projekta), CTC Upitnik za učenike (Mihić, Novak i Bašić, 2010) i Modificirana verzija Resilience and Youth Development Module (California Department of Education, 1997). U svrhu ostvarivanja cilja ovog istraživanja od statističkih metoda i analiza korištena je logistička regresijska analiza. Provedenom logističkom regresijskom analizom utvrđeno je da se na temelju spola, dobi, individualnih čimbenika otpornosti (suradnja i komunikacija, samoučinkovitost, empatija, rješavanja problema, samosvijest, ciljevi i aspiracije), čimbenika otpornosti u okruženju vršnjaka (visoka očekivanja - prosocijalni vršnjaci, brižni odnosi), čimbenika otpornosti u obiteljskom okruženju (visoka očekivanja, brižni odnosi, smislena uključenost) te čimbenika otpornosti u zajednici (visoka očekivanja, brižni odnosi, smislena uključenost) zajedno može objasniti 13,8\% doživljenog vršnjačkog nasilja barem jednom u posljednja četiri tjedna. Prediktori koji povećavaju vjerojatnost doživljenog vršnjačkog nasilja jesu ženski spol i empatija. $S$ druge strane prediktori koji smanjuju vjerojatnost doživljenog vršnjačkog nasilja jesu suradnja i komunikacija, samoučinkovitost, visoka očekivanja - prosocijalni vršnjaci te brižni odnosi s vršnjacima i u obiteljskom okruženju.

Ključne riječi: otpornost, vršnjačko nasilje, adolescenti
Izvorni znanstveni rad/Original research article UDK: 159.922.8:364.63-053.6 doi: $10.31299 /$ hrri.57.2.2

\begin{abstract}
The aim of this study is to determine the role of resilience factors in peer violence experienced by youth as the basis of planning evidence-based interventions for positive development promotion and risk behaviour prevention among youth. Our research was based on a sample of 1,647 adolescents, aged 14-19 years, from Varaždin County. The following questionnaires were used in this study: the Demographic Data Survey (developed for the purpose of this project), the CTC Youth Survey (Mihić, Novak and Bašić, 2010), and a modified version of the Resilience and Youth Development Module (California Department of Education, 1997). Using logistic regression analysis, we found that $13.8 \%$ of peer violence experienced at least once in the last four weeks can be explained by a combination of sex, age, individual resilience factors (cooperation and communication, self-efficacy, empathy, problem solving, self-awareness, goals and aspirations), resilience factors in the peer environment (high expectations - prosocial peers, caring relationships), resilience factors in the family environment (high expectations, caring relationships, meaningful participation), and resilience factors in the community (high expectations, caring relationships, meaningful participation). Predictors that increase the probability of experiencing peer violence are empathy and the female sex. On the other hand, the predictors that reduce the probability of experiencing peer violence are cooperation and communication, self-efficacy, high expectations - prosocial peers, and caring relationships with peers and family.
\end{abstract}

Keywords: resilience; peer violence; adolescents 


\section{UVOD}

Adolescencija predstavlja ključno životno razdoblje usmjereno na učenje, istraživanje te izgradnju odnosa i identiteta (Lippman, Moore i McIntosh, 2011). Popraćena je dinamičnim razvojem mozga mlade osobe oblikujući kognitivne i emocionalne obrasce kojima će se mlada osoba koristiti u odrasloj dobi (Blakemoore i Mills, 2014). Ujedno pogodan je period za jačanje otpornosti i izgradnju osnova za postizanje cjeloživotnog zdravlja i dobrobiti mlade osobe (Namy, Carlson, Pala, Faris, Knight, Allen, Devries, Naker, 2017) što se može postići uključivanjem mladih u kontekste u kojima su im osigurani pozitivni razvojni resursi. Time ne samo da se smanjuje vjerojatnost pojave nepoželjnih ponašanja i negativnih razvojnih ishoda mladih osoba već se i povećava vjerojatnost pojave socijalno kompetentnih i drugih ponašanja koja promiču zdravlje te pozitivne razvojne ishode (Youngblade, Theokas, Schulenberg, Curry, Huang, Novak, 2007). Kada su adolescenti izloženi nepovoljnim životnim okolnostima i većem broju rizičnih čimbenika, podložniji su negativnim razvojnim ishodima i iskustvima. Mnoga istraživanja potvrđuju važnost međuljudskih resursa i odnosa koji mladima pružaju sigurnost, osnovu za odsutnost nasilja te model za smanjenje problematičnih ponašanja i promociju pozitivnih ponašanja (Tobias i Chapanar, 2016). Kako bi se uspješno promicao pozitivan razvoj mladih, kao i njihova otpornost, potrebno je uključiti i uzeti u obzir višestruke kontekste, kako one bliske adolescentima, točnije njihovu obitelj, tako i one šire, što uključuje mobilizaciju škola i zajednica u pružanju podrške mladima (Youngblade, Theokas, Schulenberg, Curry, Huang i Novak, 2007). Drugim riječima, za izgradnju otpornosti potrebna je izgradnja kvalitetnog partnerstva između mladih, obitelji, škola i vršnjačkih skupina.

Istraživanja u prevencijskoj znanosti koja se fokusiraju na pronalaženje povezanosti između karakteristika pojedinca i/ili okruženja i ponašanja mladih najčešće se teorijski oslanjaju na koncept rizičnih i zaštitnih čimbenika, koncept otpornosti te koncept pozitivnog razvoja mladih. O povezanosti ovih koncepata govore mnogi autori (Barnová i Tamášová, 2018; Buchanan, 2014; Cheung, Lee,

\section{INTRODUCTION}

Adolescence is a key period in life directed towards exploration, learning, making choices, identity consolidation, and relationship building (Lippman, Moore and McIntosh, 2011). It is accompanied with dynamic brain development of a young person, shaping many of the cognitive and emotional patterns an individual will sustain in adulthood (Blakemoore and Mills, 2014). Thus, it is an opportune moment to bolster resilience and build a foundation for the life-long health and wellbeing of a young person (Namy et al., 2017): this can be achieved by involving youth in contexts providing them with developmentally supportive resources. It can not only decrease the probability of undesirable behaviours and negative developmental outcomes of a young person, but also increase the probability of socially competent and other health-promoting behaviours and positive developmental outcomes (Youngblade et al., 2007). When adolescents are exposed to unfavourable life circumstances and greater number of risk factors, they are more prone to negative developmental outcomes and experiencing peer violence. Many research studies confirm the importance of personal resources and relationships that give youth safety, foundations for absence of violence, and models to reduce problematic behaviours and promote positive behaviours (Tobias and Chapanar, 2016). In order to successfully promote positive youth development, as well as their resilience, it is necessary to consider multiple contexts, those close to the adolescents (i.e., their families) and those in broader contexts such as the mobilisation of schools and communities to provide support to youth (Youngblade et al., 2007). In other words, in order to enhance youth resilience, it is necessary to develop high-quality partnerships between youth, families, schools, and peer groups.

Research in prevention science on relationships between an individual's characteristics and/or environment and youth behaviour is most often theoretically based on the concept of risk and protective factors, as well as the concept of resilience and positive youth development. Many studies have discussed the connections between these concepts (Barnová and Tamášová, 2018; Buchanan, 2014; Cheung, Lee, Kwong and Busiol, 2015; Forrest- 
Kwong i Busiol, 2015; Forrest-Bank, Nicotera, Anthony i Jenson, 2015; Lerner i sur., 2013).

Koncept rizičnih i zaštitnih čimbenika polazi od ideje kako čimbenici koje nosi pojedinac ili oni koji se nalaze u njegovu okruženju mogu imati utjecaj na razvojne ishode mladih. Zaštitni se čimbenici definiraju kao oni koji štite od posljedica izloženosti rizičnim čimbenicima i to kroz smanjivanje utjecaja rizika ili utjecanja na način na koji će mladi ljudi odgovoriti na rizik, odnosno rizične čimbenike (Bašić i Ferić, 2004). S druge strane rizični su čimbenici karakteristike, varijable ili opasnosti koje, ako su prisutne kod određenog pojedinca ili okruženja u kojem živi, mogu s većom vjerojatnosti dovesti do nepovoljnih ishoda nego kod onih pojedinaca koji nisu izloženi tim rizicima. Važno je još napomenuti kako su razvojni ishodi mladih pod utjecajem složenih procesa interakcija između (moguće) više rizičnih i zaštitnih čimbenika (Bašić, 2009).

Koncept otpornosti najčešće se definira kao pozitivna prilagodba usprkos negativnim događajima (Luthar, 2006), odnosno sposobnost dinamičkog sustava da se uspješno prilagodi smetnjama koje prijete njegovoj održivosti, razvoju ili funkcioniranju (Masten, 2014). U protekla se četiri desetljeća shvaćanje ovog naizgled jednostavnog koncepta mijenjalo, pa se tako krajem prošloga stoljeća otpornost pojašnjavala prvenstveno kao individualna karakteristika pojedinca (Anthony, 1987) dok se u novije vrijeme konceptualizacija otpornosti usmjerava na socijalnoekološke čimbenike koji, prema Ungar (2011), olakšavaju pozitivan razvoj uslijed doživljenog stresa. Time se naglasak stavlja na procese kojima si pojedinci i skupine (primjerice obitelj, vršnjaci i zajednice) osiguravaju psihološke, socijalne i fizičke izvore koji povećavaju vjerojatnost uspješnog razvoja u nepovoljnim okolnostima (Ungar, Ghazinour, Richter, 2013). Individualna otpornost sposobnost je brzog oporavka pojedinca usred problemske situacije, odnosno neugodnog i stresnog događaja, pri čemu je oporavak popraćen nadvladavanjem izvora stresa u odsustvu disfunkcionalnih ponašanja (Magis, 2010). Obiteljska otpornost podrazumijeva suočavanje obitelji s izvorom stresa te procesnu prilagodbu na stresnu situaciju ili krizu (Berc, 2012), dok se
Bank, Nicotera, Anthony and Jenson, 2015; Lerner et al., 2013).

The concept of risk and protective factors is founded on an idea that factors within an individual or from an individual's environment may bear an impact on developmental outcomes for youth. Protective factors are defined as those that protect from the consequences of exposure to risk factors through reduction of risk impact or by impacting the way in which young people respond to risk or risk factors (Bašić and Ferić, 2004). In contrast, risk factors are characteristics, variables, or dangers that when presented in a certain individual or individual's environment carry a higher probability of leading to undesirable outcomes compared to others who are not exposed to these risks. It is important to emphasise that youth developmental outcomes are under the impact of complex interaction processes between (possibly) multiple risk and protective factors (Bašić, 2009).

The concept of resilience is most often defined as positive adaptation despite negative events (Luthar, 2006) i.e., the capacity of a dynamic system to adapt successfully to disturbances that threaten the viability, function, or development of the system (Masten, 2014). In the past four decades, comprehension of this seemingly simple concept has changed. At the end of the last century, resilience was explained primarily as individual characteristics of a person (Anthony, 1987), while more recently the resilience concept is more focused towards social environmental factors that, according to Ungar (2011), enable positive development through stressful experiences. This places an emphasis on the processes that give individuals and groups (for example, family, peers, and the community) the psychological, social, and physical resources to increase the likelihood of successful development in unfavourable circumstances (Ungar, Ghazinour and Richter, 2013). Individual resilience is the capacity of an individual to recover from a challenging or stressful situation, and this recovery occurs by overcoming the source of stress without casuing dysfunctional behaviours (Magis, 2010). Family resilience refers to a family facing a challenging situation and family's adaptation process to this stressful situation or crisis (Berc, 2012), while community resilience refers to the sustainable and successful adaptation of the community to new changes (Magis, 2010). 
otpornost zajednice odnosi na održivost i uspješnu prilagodbu zajednice na novonastale promjene (Magis, 2010).

Koncept pozitivnog razvoja naglašava kako je pozitivan razvoj mladih omogućen kada se njihove osobne snage udruže s izvorima zdravog razvoja u obitelji, školi i zajednici (Benson, Scales, Hamilton i Sesma, 2007). Svaka mlada osoba ima urođen potencijal za pozitivan rast i razvoj (Damon, 2004), a pozitivna je razvojna putanja vjerojatnija kada je mlada osoba uključena u odnose, kontekste i okruženja koja potiču njezin razvoj (Lerner, 2003; Lerner, Phelps, Forman i Bowers, 2009). Pozitivan razvoj mladih predstavlja odsustvo rizičnih oblika ponašanja (Benson, 2003).

Kada se govori o povezanosti navedenih koncepata, Lerner (2003) navodi kako je otpornost integrirani dio koncepta pozitivnog razvoja mladih, kojim se naglašava dinamična priroda dvosmjernih interakcija između pojedinca i okruženja. Masten (2014) pak ističe kako je u oba koncepta fokus na istraživanju snaga i kompetencija. Koncept otpornosti vezan je i uz koncept rizičnih i zaštitnih čimbenika u identifikaciji zaštitnih čimbenika koji umanjuju utjecaj rizičnih čimbenika te vode pozitivnim razvojnim ishodima (Belošević i Ferić, 2020). Više o povezanosti koncepta otpornosti i koncepta pozitivnog razvoja moguće je naći u radu koji potpisuju Novak, Ferić, Kranželić i Mihić (2019).

Bez obzira na to koji je koncept korišten $\mathrm{u}$ istraživanju čimbenika koji su povezani s razvojnim ishodima mladih, postoji svojevrstan konsenzus autora oko čimbenika koji podržavaju pozitivne razvojne ishode. Čimbenici koje nosi pojedinac odnose se na osobine i vještine mladih osoba, dok čimbenici u okruženju uključuju podršku obitelji, škole, vršnjaka i zajednice (Nearchou, Stogiannidou i Kiosseoglou, 2014), ali i visoka očekivanja i poticanje mladih na uključenost (Cambron, Catalano i Hawkins, 2019). Individualni čimbenici rezultat su načina na koji mlada osoba doživljava svoju obitelj, vršnjake, školu i zajednicu te upućuju na to je li okruženje mlade osobe podržavajuće i pruža li mogućnost za pozitivan razvoj (Parsai, Voisine, Marsiglia, Kulis i Nieri, 2008). Obje skupine čimbenika mogu izravno utjecati na vjerojatnost pozitivnih razvojnih ishoda djeteta $i$
The concept of positive youth development emphasises that positive youth development is possible when personal strengths join with sources of healthy development in the family, their school, and the community (Benson, Scales, Hamilton and Sesma, 2007). Every young person has a built-in potential for growth and positive development (Damon, 2004). Positive development is more probable when youth are involved in relationships, contexts, and environments that stimulate individual growth (Lerner, 2003; Lerner, Phelps, Forman and Bowers, 2009). Positive development constitutes the absence of risky forms of behaviour (Benson, 2003).

When discussing the interconnectedness between the above-mentioned concepts, Lerner (2003) stated that resilience is an integral part of the positive youth development concept, emphasising the dynamic nature of two-way interactions between individuals and the environment. Masten (2014), on the other hand, emphasised that, in both concepts, the research focus must be placed on strengths and competencies. The resilience concept is tied to the concept of risk and protective factors in identifying protective factors that decrease the impact of risk factors and lead to positive developmental outcomes (Belošević and Ferić, 2020). Further information on interconnectedness between resilience and positive development can be found in Novak, Ferić, Kranželić and Mihić (2019).

Regardless of which concept is applied in the research of factors related to youth developmental outcomes, there is consensus among researchers on the factors that support positive developmental outcomes. Factors within the individual refer to traits and skills of young persons, while environment factors include support from family, school, peers, and the community (Nearchou, Stogiannidou and Kiosseoglou, 2014), as well as high expectations and enticing youth participation (Cambron, Catalano and Hawkins, 2019). Individual factors stem from the way a young person experiences his or her family, peers, schools, and the community, and therefore, they can indicate whether this young person's environment is supportive and whether it provides opportunities for positive development (Parsai, Voisine, Marsiglia, Kulis and Nieri, 2008). Both groups of factors may have a 
na smanjenje negativnih učinaka stresnih događaja. Pozitivan razvoj mladih, kao i njihova otpornost, povezani su s pozitivnom slikom o sebi, unutrašnjim lokusom kontrole, preuzimanjem odgovornosti, orijentiranošću na postignuća te s imanjem barem jednog bliskog prijateljskog odnosa (Shean, 2015). Masten i Barens (2018) kao neke od značajnijih individualnih zaštitnih čimbenika koji promiču otpornost navode bivanje u bliskim odnosima, emocionalnu sigurnost i pripadanje, proaktivnost (djelovanje i motivacija za prilagodbu), vještine rješavanja problema, vještine samoregulacije emocija, samoučinkovitost i pozitivan pogled na sebe.

U odnosu na okruženja u kojima mladi žive i provode najveći dio svojeg vremena, Parsai i suradnici (2008) ističu kako doživljaj obitelji, vršnjačke grupe, škole i zajednice kao podržavajućih, brižnih, s mnoštvom mogućnosti za smislenu uključenost i doprinos, dovodi do razvoja individualnih karakteristika koje definiraju njihov pozitivan razvoj i uspješno učenje te ih štite od rizičnih ponašanja. Odnosi s brižnim odraslima identificirani su kao zaštitni izvori za djecu i adolescente, a ti odnosi mogu uključivati veze s roditeljima (ili skrbnicima), ali i drugim brižnim odraslim osobama. Povezanost s roditeljima i obitelji može nadomjestiti izloženost riziku i niz negativnih ishoda (Zimmerman, Stoddard, Eisman, Caldwell, Aiyer i Miller, 2013). Odnosi roditelja i adolescenata imaju zaštitnu funkciju stvaranjem "sigurne baze" za adolescente (Hair, Moore, Garrett, Ling i Cleveland, 2008). Tako se podrška roditelja povezuje s rjeđim nasilnim ponašanjem mladih koji su bili svjedoci nasilja (Zimmerman i sur., 2013). Privrženost adolescenata roditeljima pridonosi njihovoj socijalnoj kompetenciji, snalaženju i samopoštovanju (Piko i Kovács, 2010). Nadalje škola također može značajno utjecati na psihosocijalni razvoj adolescenta. Naime školska klima, privrženost školi i učiteljima mogu predstavljati izvor zaštite pogotovo jer mladi provode mnogo vremena u školskom okruženju (Fitzpatrick, Piko i Wright, 2005; Piko i Kovács, 2010). S obzirom na to da mladi provode i značajan dio vremena sa svojim vršnjacima te da od njih učestalo traže odobrenje, vrsta odnosa koju će razviti bit direct impact on the probability of positive developmental outcomes of a child and on reduction of negative impacts of stressful events. Positive youth development, as well as their resilience, is related to positive self-concept, internal locus of control, taking responsibility, focus on achievements, and having at least one close friend (Shean, 2015). Masten and Barens (2018) state that some of the more significant individual protective factors that contribute to resilience are close relationships, emotional security and belonging, proactivity (action and motivation to adapt), problem-solving skills, self-regulation skills, self-efficacy, and positive view of the self.

Regarding the environment in which young people live and spend most of their time, Parsai et al. (2008) emphasised that experiencing family, peer group, school, and community as supportive, caring, with plenty of opportunities for meaningful participation and contribution, results in the development of personal traits that define their positive development and successful learning, and hence, protect them from risk behaviours. Relationships with caring adults are identified as sources of protection for children and adolescents: these relationships may include bonds with parents (or guardians), and other caring adults. Bonds with parents and family help to compensate for the exposure to risk and associated negative outcomes (Zimmerman et al., 2013). Relationships between parents and adolescents plays a protective role by creating a "safe base" for adolescents (Hair, Moore, Garrett, Ling and Cleveland, 2008). Parental support is correlated with less violent behaviours among youth witnesses of violence (Zimmerman, Steinman and Rowe, 1998, according to Zimmerman et al., 2013). Adolescent attachment to parents may contribute to social competence, coping skills, and self-esteem (Piko and Kovács, 2010).

Furthermore, the school may have a significant impact on psychosocial development of adolescents. School climate and school attachment can serve as a source of protection for youth, particularly because youth spend a great deal of time in school (Fitzpatrick, Piko and Wright, 2005; Piko and Kovács, 2010). Given the fact that youth spend a significant portion of their time with peers, and that they frequently seek their approval, the type 
će od izuzetne važnosti za njihov rast i razvoj (Parsai i sur., 2008). Mnogobrojne su pozitivne funkcije prijateljstva, uključujući informiranje mlade osobe o njezinoj vrijednosti, poticanje na stjecanje novih vještina, ali i zaštitu od negativnih čimbenika (Bollmer, Milich, Harris i Maras, 2005). Kvalitetna prijateljstva mogu zaštititi mlade od vršnjačke viktimizacije i ublažiti nasilna ponašanja.

U radovima se mogu pronaći različiti modeli operacionalizacije otpornosti $u$ istraživačke svrhe. $\mathrm{U}$ ovom radu otpornost je operacionalizirana kroz model otpornosti i razvoja mladih koji je temeljen na snagama mladih i pretpostavlja vanjske zaštite (bliski odnosi, visoka očekivanja i smislenu uključenost u obitelji i zajednici te bliske odnose i visoka očekivanja s vršnjacima) te unutarnje zaštite - suradnja i komunikacija, samoučinkovitost, empatija, rješavanje problema, samosvijest te imanje ciljeva i visokih aspiracija (Constantine i Bernard, 2001).

\section{Nasilje među vršnjacima}

Nasilje među učenicima karakteriziraju različiti oblici agresivnog ponašanja i uznemiravanja od strane vršnjaka te je čest problem među djecom i mladima diljem svijeta (Craig i sur., 2009; Hirschtritt, Ordóñez, Rico i Lewinn, 2015). Na području Europe više od 15000 mladih u dobi od 15 do 29 godina umire od posljedica nasilja, a mnogo ih je više hospitalizirano i trpi fizičke, emocionalne, psihološke ili socijalne posljedice zbog svjedočenja ili sudjelovanja u nasilju te straha od nasilja (Mitis, Sethi, Crispino i Galea, 2014; Sethi, Hughes, Bellis, Mitis i Racioppi, 2014). Posljedice vršnjačkog nasilja mogu biti ozbiljne i dugotrajne te uključuju nisko samopoštovanje, depresiju, akademski neuspjeh, probleme u ponašanju, psihozu i povećani rizik od samoubojstva (Arseneault, Bowes i Shakoor, 2009; Barker, Arseneault, Brendgen, Fontaine i Maughan, 2008; Klomek, Sourander i Gould, 2010; Schreier i sur., 2009). Vršnjačko nasilje (engl. peer violence) podrazumijeva različite oblike agresivnog ponašanja nasilnika prema žrtvi, a čija namjera ne mora biti jasno izražena (Hawley i Vaughn, 2003; Rajhvajn Bulat i Ajduković, 2012; Velki, 2019). Vršnjačko nasilje može biti izravno (fizička agre- of relationships that they develop will be of outmost importance for their growth and development (Parsai et al., 2008). Friendships are believed to serve many functions, including informing individuals of their value, promoting the exploration and acquisition of new skills, and providing a protective buffer against negative factors (Bollmer, Milich, Harris and Maras, 2005). Friendship quality is a protective factor in peer victimisation and may mitigate bullying.

There are different models of operationalising resilience for research purposes. In this paper, resilience is operationalised through a model of resilience and youth development that is based on youth assets, and assumes the existence of certain external protective assets (close relationships, high expectations, meaningful participation in family and community, and close relationships and high expectations with peers) and internal protective assets (cooperation and communication, self-efficacy, empathy, problem solving, self-awareness, and having goals and high aspirations) (Constantine and Bernard, 2001).

\section{Peer violence}

Peer violence is characterised by different forms of aggressive behaviour and harassment from peers. It is a frequent problem among children and youth worldwide (Craig et al., 2009; Hirschtritt, Ordóñez, Rico and Lewinn, 2015). In Europe, more than 15,000 youth, aged 15 to 29 years, lose their lives as a consequence of peer violence, and many more are hospitalised or suffer from physical, emotional, psychological, or social consequences from participating in violence, as well as witnessing or fearing violence (Mitis, Sethi, Crispino and Galea, 2014; Sethi, Hughes, Bellis, Mitis and Racioppi, 2014). Consequences of peer violence may be serious and long-term, including low self-esteem, depression, academic failure, behavioural problems, psychosis, and increased suicide risk (Arseneault, Bowes and Shakoor, 2009; Barker, Arseneault, Brendgen, Fontaine and Maughan, 2008; Brunstein Klomek, Sourander and Gould, 2010; Schreier et al., 2009). Peer violence includes different forms of aggressive behaviour that a bully exerts on his victim, and often its intent is not clearly expressed (Hawley and Vaughn, 2003; 
sija, prijetnje i zadirkivanje) ili neizravno (širenje glasina i isključenje iz grupa vršnjaka) (Corboz, Hemat, Siddiq i Jewkes, 2018), a može uključivati i zlostavljanje (engl. bullying) koje je općenito usmjerenija i kroničnija vrsta vršnjačkog nasilja (Juvonen i Graham, 2014). Vršnjačko zlostavljanje definirano je kao oblik agresivnoga ponašanja u kojem postoji nesrazmjer moći između djeteta nasilnika i djeteta žrtve gdje nasilnik ima veću moć, a takvo se ponašanje učestalo ponavlja (Velki i Vrdoljak, 2013). U ovom istraživanju istraživano je doživljeno vršnjačko nasilje te su u skladu s tim u nastavku rada prikazani rezultati i rasprava.

Nasilje među djecom i mladima predstavlja ozbiljan javnozdravstveni problem (Lin, Yu, Chen, Tian i Zhang, 2018). Nalazi metaanaliza pokazuju da je približno jedno od troje djece uključeno u neki od oblika nasilja (Modecki Minchin, Harbaugh, Guerra i Runions, 2014). Međutim prevalencija iskustva doživljenog vršnjačkog nasilja među djecom u školskom okruženju globalno se razlikuje (Corboz i sur., 2018). Rezultati istraživanja sugeriraju da je 20,2\% djece između 12 i 18 godina izvijestilo o doživljenom vršnjačkom nasilju u školi u SAD-u (U.S. Department of Education, 2019), dok je između 7\% i 59\% djece u zemljama jugoistočne Azije izvijestilo da su bili zlostavljani od strane vršnjaka (Sittichai i Smith, 2015). Nadalje rezultati svjetskih istraživanja među učenicima u dobi od 10 do 18 godina pokazuju da je među njima od 3\% do 12,9\% počinitelja vršnjačkog nasilja te od 5\% do 6\% žrtava (Cross, Shaw, Epstein, Monks, Dooley i Hearn, 2012; Velki, 2019). Podaci o prevalenciji vršnjačkog nasilja koji se odnose na područje Republike Hrvatske također variraju, ovisno o dobi ispitanika te oblicima ispitivanog nasilja (Reić Ercegovac, 2016). Velki i Vrdoljak (2013) izvještavaju da je oko $31 \%$ učenika od 5. do 8. razreda u dvije osnovne škole na području Slavonije doživjelo vršnjačko nasilje, dok Vlah i Perger (2014) na uzorku učenika od 4. do 8. razreda jedne osnovne škole na području Ličko-senjske županije izvještavaju kako je vršnjačkom nasilju barem jedanput bilo izloženo $60,5 \%$ učenika dok je njih $20 \%$ često doživljavalo vršnjačko nasilje u posljednjih nekoliko mjeseci. Nadalje međunarodno istraživanje o zdravstvenom ponašanju uče-
Rajhvajn Bulut and Ajduković, 2012; Velki, 2019). Peer violence may be direct (physical aggression, threats and teasing) or indirect (spreading rumours and exclusion from peer groups) (Corboz, Hemat, Siddiq and Jewkes, 2018), and may involve bullying, which is generally a more targeted and chronic, repetitive type of peer violence (Juvonen and Graham, 2014). Peer violence is defined as a form of aggressive behaviour in which there is a disproportion in power between the child who is a bully and the child who is a victim, where the bully has greater power and such behaviour is frequently repeated (Velki and Vrdoljak, 2013). The present study explores youth who have experienced peer violence.

Peer victimisation among children and youth is a serious public health problem ( $\mathrm{Lin}, \mathrm{Yu}, \mathrm{Chen}$, Tian and Zhang, 2018). Meta-analysis findings show that one out of three children are involved in some form of violence (Modecki et al., 2014). However, the prevalence of peer violence among children in school environments differs across the globe (Corboz, Hemat, Siddiq and Jewkes, 2018). Results suggest that $20.2 \%$ of children between the ages of 12 and 18 years reported that they experienced peer violence in schools in the United States (U.S. Department of Education, 2019), while between $7-59 \%$ of children in Southeast Asian countries reported that they were bullied by their peers (Sittichai and Smith, 2015). Furthermore, results of global research among students aged 10 to 18 years suggests that there are between $3-12.9 \%$ of youth committing peer violence and between 5-6\% who are victims (Cross et al., 2012; Velki, 2019). Data on peer violence prevalence in Croatia also varies depending on the age of participants and the type of violence in question (Reić Ercegovac, 2016). Velki and Vrdoljak (2013) reported that approximately $31 \%$ of students from grade 5 to 8 in two elementary schools in Slavonia experienced peer violence, while Vlah and Perger (2014) reported that $60.5 \%$ of students from grade 4 to 8 in one elementary school in Lika-Senj County were exposed to peer violence at least once, and $20 \%$ of them have frequently experienced peer violence in the past few months. An international research study was conducted in 2018 by Health Behaviour in School aged Children (HBSC) across 50 coun- 
nika (Health Behaviour in School aged Children, $H B S C$ ) koje se provodi u 50 zemalja i regija Europe i Sjeverne Amerike, uključujući i Hrvatsku, provelo je posljednje istraživanje 2018. godine u kojem je sudjelovalo 5169 učenika i učenica iz Hrvatske u dobi od 11, 13 i 15 godina (Capak, 2020). Podaci za Hrvatsku pokazuju da je na pitanje jesu li bili zlostavljani od strane vršnjaka najmanje dvaput unazad nekoliko mjeseci u dobi od 11 godina afirmativno odgovorilo $14,1 \%$ dječaka i $9,7 \%$ djevojčica, u dobi od 13 godina 12,6\% dječaka i 11,3\% djevojčica, a u dobi od 15 godina $8,3 \%$ dječaka i $7,7 \%$ djevojčica. U Hrvatskoj je nešto više zlostavljanih u nižim dobnim skupinama u odnosu na prosjek u istraživanje uključenih zemalja, dok smo u dobi od 15 godina jednaki prosjeku tih zemalja. Ujedno podaci pokazuju kako je Hrvatska deseta zemlja po redu prema udjelu učenika koji su u dobi od 13 godina prijavili vršnjačko zlostavljanje drugih barem dva ili tri puta u posljednjih nekoliko mjeseci (Capak, 2020).

Literatura o čimbenicima rizika za vršnjačko nasilje opsežna je te identificira niz čimbenika povezanih s vršnjačkim nasiljem. Rizični čimbenici javljaju se na razini pojedinca, obiteljskih i vršnjačkih odnosa, zajednice i društva. Važno je imati na umu da što se više rizičnih čimbenika akumulira u pojedincu ili u određenom okruženju, to je veća vjerojatnost da će se pojedinac uključiti u neki oblik vršnjačkog nasilja nad mladima ili da će se nasilje dogoditi u određenom okruženju (World Health Organization, 2015). Primjerice na individualnoj razini vršnjačko nasilje obično je povezano s nizom sociodemografskih, fizičkih, psiholoških i relacijskih čimbenika (Corboz, Hemat, Siddiq i Jewkes, 2018). Istraživanja pokazuju da je muški spol prediktor vršnjačkog nasilja, odnosno veća je vjerojatnost da će dječaci biti uključeni u vršnjačko nasilje, bilo kao žrtve bilo kao počinitelji vršnjačkog nasilja (De Bolle i Tackett 2013; De Bruyn, Cillessen i Wissink, 2010; Espejo-Siles, Zych, Farrington i Llorent, 2020; Košir i sur., 2020; WHO, 2015). Navedeni rezultati podudarni su s tendencijom osoba muškog spola da se više moralno distanciraju (Paciello, Fida, Tramonato, Lupinetti i Caprara, 2008; Zych i Llorent, 2019).

Nadalje istraživanja pokazuju kako unutarnje prednosti i vanjski resursi u okruženjima tries and regions in Europe and North America, including Croatia (Capak, 2020). Based on data from 5,169 Croatian students, aged 11, 13, and 15 years, they showed that among the 11-year-olds, $14.1 \%$ of boys and $9.7 \%$ of girls were abused at least twice in the past couple of months. This was the case also for $12.6 \%$ of boys and $11.3 \%$ of girls aged 13 years, and for $8.3 \%$ of boys and $7.7 \%$ of girls aged 15 years. In Croatia, the proportion of children who experienced per violence was slightly high compared to the average in other HBSC countries in younger age groups: with respect to the 15-year-olds, the proportion of children in Croatia who suffered peer violence was equal to that observed in other HBSC countries. Furthermore, data shows that Croatia ranks tenth based on the number of 13-year-olds who reported peer violence of others at least two or three times in the past few months (Capak, 2020).

Literature on risk factors for peer violence is extensive, and it clearly identifies a series of factors related to peer violence. Risk factors may occur at the level of an individual, family, and peer relationships, as well as the community and society. It is important to bear in mind that if more risk factors accumulate within an individual or certain environment, there is a greater probability that the individual will be involved in some form of youth peer violence or that violence is going to happen in a certain environment (World Health Organization, 2015). For example, at the individual level, peer violence is usually related to a series of sociodemographic, physical, psychological, and relational factors (Corboz, Hemat, Siddiq and Jewkes, 2018). Research shows that male sex is a predictor of peer violence (i.e.,) there is a greater probability that boys will be involved in peer violence, either as victims or perpetrators (De Bolle and Tackett 2013; De Bruyn, Cillessen and Wissink, 2010; EspejoSiles, Zych, Farrington and Llorent, 2020; Košir et al., 2020; Ma 2002; Nansel et al. 2001; WHO, 2015). The above-mentioned results also coincide with the tendency of the male sex to be more morally distanced (Paciello, Fida, Tramonato, Lupinetti and Caprara, 2008; Zych and Llorent, 2019).

Furthermore, research shows that internal assets as well as external resources in the environment can directly reduce the probability of negative 
mogu izravno umanjiti vjerojatnost negativnog ponašanja poput nasilja. Primjerice optimistični ciljevi i aspiracije o budućnosti mogu poslužiti kao motivacija za postizanje pozitivnih ishoda $i$ put k uspjehu smanjujući tako sklonost nasilju (Sun i Shek, 2012). Ujedno istraživanja pokazuju kako na individualnoj razini snižene emocionalne kompetencije i inteligencija predviđaju vršnjačko nasilje i zlostavljanje (McLaughlin, Hatzenbuehler, Mennin i Nolen-Hoeksema, 2011; Peachey, Wenos i Baller, 2017; Schokman i sur., 2014; Velki, 2019).

Osim individualnih karakteristika značajnu ulogu tijekom razdoblja adolescencije imaju i odnosi s vršnjacima. Istraživanja pokazuju da je doživljeno vršnjačko nasilje povezano s poteškoćama u međuljudskim odnosima općenito, odnosno da mladi koji percipiraju niže razine podrške od strane vršnjaka izvještavaju o višoj razini doživljenog vršnjačkog nasilja (Cook, Williams, Guerra, Kim i Sadek, 2010; Košir i sur., 2019). Štoviše, djeca i mladi koji izvještavaju o doživljenom vršnjačkom nasilju često se osjećaju usamljeno i isključeno te su nezadovoljni svojim odnosima s vršnjacima (Rudolph i sur., 2014). Ujedno imaju generalno niži stupanj prihvaćenosti od strane vršnjaka zbog postupnog odbacivanja od strane pojedinaca te je vjerojatnije da će se povezati s delinkventnim vršnjacima (Kochel, Ladd i Rudolph, 2012). Delinkventna pripadnost vršnjaka odnosi se na povezanost adolescenata s vršnjacima koji se uključuju u delinkventna ponašanja poput tučnjave, krađe i konzumacije alkohola (Zhu, Zhang, Yu i Bao, 2015). S druge strane istraživanja pokazuju kako upravo roditeljsko sudjelovanje u životu mladih potiče i podržava njihov prosocijalni izbor, što dovodi do smanjenog sudjelovanja u rizičnim i nasilnim ponašanjima (Ali, Swahn i Sterling, 2001). Također istraživanja u školskom okruženju pokazuju da socijalna podrška od strane obitelji i prijatelja štiti adolescente koji su žrtve vršnjačkog nasilja od lošijeg akademskog uspjeha i suicidalnih ideja (Rothon, Head, Klineberg i Stansfeld, 2011; Hirschtritt i sur., 2015).

Iako je važno skrenuti pozornost na ozbiljnost nasilja, također je važno imati na umu da pojedinci posjeduju individualne osobine te razne resurse behaviour, such as violence. For example, optimistic goals and aspirations about the future may serve as motivation for achieving positive outcomes and paths to success, therefore reducing the tendency towards violence (Sun and Shek, 2012, according to Stoddard, Heinze, Choe and Zimmerman, 2015). Furthermore, research shows that, at the individual level, reduced emotional competencies and intelligence predict peer violence and abuse (McLaughlin et al., 2011; Peachey, Wenos and Baller, 2017; Schokman et al., 2014, Velki, 2019).

Besides individual characteristics, relationships with peers play a significant role during adolescence. Research shows that the experience of peer violence is related to difficulties in relationships in general (i.e.,) young people who perceive low levels of support from their peers report higher levels of peer violence (Cook et al. 2010; Košir et al., 2019). Moreover, children who have experienced peer violence tend to become youth who often feel lonely and excluded and are unhappy with their peer relationships (Rudolph et al., 2014). They are also less accepted by their peers due to gradual rejection from certain peers, and this makes it more probable that they will connect with delinquent peers (Kochel et al., 2012). Delinquent peer affiliation refers to adolescent affiliation with peers who engage in deviant behaviours such as fighting, stealing, and alcohol use (Zhu et al., 2015). On the other hand, research shows that parental participation in the lives of youth improves prosocial choices, leading to reduced participation in risky and violent behaviours (Ali, Swahn and Sterling, 2001). Moreover, research studies in school settings show that social support from family and friends can protect adolescents who are victims of peer violence from lower academic success and suicidal ideas (Rothon, Head, Klineberg and Stansfeld, 2011, Hirschtritt, Ordóñez, Rico and Lewinn, 2015).

Although it is important to focus our attention on the seriousness of the violence as such, it is also important to bear in mind that individuals may possess certain traits and different resources within their family or community that can help them overcome the experience of violence. Individual, family, and societal factors may serve as protective factors for adolescents who experience peer violence. If an individual experiences peer vio- 
unutar svoje obitelji ili zajednice, koje im mogu pomoći da prevladaju iskustvo nasilja. Gledajući iz prizme koncepta otpornosti koji govori o tome da se otpornost razvija i u situacijama izloženosti riziku (nedaći, nepovoljnom životnom iskustvu), iskustvo vršnjačkog nasilja ne vodi nužno negativnim razvojnim ishodima. Jačajući individualne, obiteljske i društvene čimbenike koji djeluju kao zaštitni čimbenici za adolescente koji su doživjeli vršnjačko nasilje podržava se proces uspješnog suočavanja mladih s negativnim iskustvima tijekom odrastanja. Identifikacija čimbenika koji promiču pozitivne razvojne ishode mladih koji su doživjeli negativne situacije poput vršnjačkog nasilja važna je za razvoj i unaprjeđenje intervencija namijenjenih žrtvama vršnjačkog nasilja. Svrha je ovog istraživanja upravo utvrditi doprinos čimbenika otpornosti u objašnjenju doživljenog vršnjačkog nasilja kao temelju planiranja znanstveno utemeljenih intervencija za promociju pozitivnog razvoja/prevenciju rizičnih ponašanja mladih.

\section{CILJEVI ISTRAŽIVANJA}

Cilj je ovog rada utvrditi doprinos demografskih varijabli (spol i dob), individualnih čimbenika otpornosti (suradnja i komunikacija; samoučinkovitost; empatija; rješavanje problema; samosvijest; ciljevi i aspiracije), čimbenika otpornosti u okruženju vršnjaka (visoka očekivanja - prosocijalni vršnjaci, brižni odnosi), čimbenika otpornosti u obiteljskom okruženju (visoka očekivanja, brižni odnosi, smislena uključenost) i čimbenika otpornosti u zajednici (visoka očekivanja, brižni odnosi, smislena uključenost) u objašnjenju doživljenog vršnjačkog nasilja od strane mladih na području Varaždinske županije.

\section{METODE}

\section{Uzorak ispitanika}

U istraživanju je sudjelovalo 1647 učenika Varaždinske županije, a provedeno je u okviru projekta "Pozitivan razvoj adolescenata u Hrvatskoj (PRAG - HR)"tijekom 2018. godine, a u kojem je sudjelovalo ukupno 10138 učenika. Uzorak je kvotni s obzirom na tri hrvatska srednjoškolska programa (trogodišnji strukovni lence, it does not necessarily mean that they will experience negative developmental outcomes. Certain individual strengths and factors in the environment may reduce the probability of negative developmental outcomes. Recognising factors that promote positive developmental outcomes of youth who experienced negative events, such as peer violence, can be used to improve the development of interventions for peer violence victims. The purpose of the present study is to determine the contribution of resilience factors in explaining peer violence experiences as the basis for planning evidence-based interventions in the field of positive youth development promotion and youth risk behaviour prevention.

\section{RESEARCH AIM}

The aim of this paper is to determine the contribution of demographic variables (age and sex), individual resilience factors (cooperation and communication; self-efficacy; empathy; problem-solving; self-awareness; goals and aspirations), resilience factors in the peer environment (high expectations - prosocial peers, caring relationships), resilience factors in the family environment (high expectations, caring relationships, meaningful participation), and resilience factors in the community (high expectations, caring relationships, meaningful participation) in explaining peer violence experienced by youth from Varaždin County.

\section{METHODS}

\section{Participants}

This study was conducted in 2018 as part of the "Positive Development of adolescents in Croatia (PRAG-HR)" research project, which involved a total of 10,138 students. Our sample comprised of 1,647 students, aged 14-19 years, from Varaždin County: this is a quota sample based on three Croatian high school programs (three-year vocational program, four-year vocational program, and gymnasium program), number of students per grade, and education programs within each of these schools. The sample accounts for $30 \%$ of high school students in Varaždin, which is representative of the total population of high-school students in Varaždin County based on a given set 
program, četverogodišnji strukovni program i gimnazijski program), broj učenika po razredima kao i pojedinačne obrazovne programe unutar svake od škola. Uzorak u istraživanju čini oko $30 \%$ populacije varaždinskih srednjoškolaca koji u omjeru zadanih kriterija (tip srednjoškolskog programa, razred, obrazovni program) oslikava ukupnu populaciju srednjoškolaca na području Varaždinske županije.

Uzorak je činilo 45\% djevojaka $(\mathrm{N}=762)$ i $53 \%$ mladića $(\mathrm{N}=848)$, a za $2 \%$ sudionika istraživanja nema podataka $(\mathrm{N}=37)$. Raspon dobi kreće se od 14 do 19 godina, a prosječna je dob sudionika 16 godina $(\mathrm{M}=16,25, \mathrm{SD}$ dob $=1,206)$. Istraživanje je provedeno u devet srednjih škola te su uključeni učenici gimnazijskog $(23,2 \%, N=382)$, četverogodišnjeg $(55,1 \%, \mathrm{~N}=908)$ i trogodišnjeg programa $(21,7 \%, \mathrm{~N}=357)$.

\section{Postupak provedbe istraživanja}

Istraživanje je provedeno u suglasju s odredbama Etičkog kodeksa istraživanja s djecom (2003), a za njegovo provođenje dobivena je suglasnost Etičkog povjerenstva Edukacijskorehabilitacijskog fakulteta Sveučilišta u Zagrebu i Ministarstva znanosti i obrazovanja. Primjena upitnika provedena je u školama, u manjim skupinama do 30 učenika, metodom papir-olovka. Predviđeno vrijeme za ispunjavanje anketnog upitnika bilo je 45 minuta, a učenicima je ponuđena pomoć u smislu dodatnog pojašnjenja pojedinih pitanja. Sudjelovanje u istraživanju bilo je dobrovoljno i svi sudionici dali su pisanu suglasnost za sudjelovanje u istraživanju na obrascu koji je sadržavao informacije o istraživanju i njegovim ciljevima, načinima postupanja s podacima, o pravima i zaštiti sudionika te eventualnim rizicima. Iako prema Etičkom kodeksu istraživanja s djecom (2003), djeca starija od 14 godina daju samostalni pristanak za sudjelovanje u istraživanju, nekoliko škola zahtijevalo je i suglasnost roditelja za sudjelovanje njihove djece u istraživanju kako bi se ispoštovale odredbe GDPR-a. $\mathrm{S}$ obzirom na navedeno u školama koje su to zahtijevale od roditelja je zatražena i dobivena pisana suglasnost za sudjelovanje njihova djeteta $u$ istraživanju. Sudionici su prije primjene upitnika usmeno bili upoznati sa svrhom i cilje- of criteria (type of high-school program, grade, education program).

The sample consists of 762 girls (45\%), 848 boys $(53 \%), 37$ participants $(2 \%)$ with no gender information. The average age of the participants is 16 years $(16.25 \pm 1.206)$. Research was conducted in nine high schools and included 382 students $(23.2 \%)$ enrolled in Gymnasiums, 908 students $(55.1 \%)$ enrolled in four-year vocational programs, and 357 students $(21.7 \%)$ enrolled in three-year vocational programs.

\section{Research process}

After receiving the approval of the Ethics Committee of the Faculty of Education and Rehabilitation Sciences at the University of Zagreb and the Ministry of Science and Education, this study was performed in accordance with the provisions outlined in the Ethics Code for Researching Children (2003). The pen and paper method was used to fill out the questionnaires in different schools, and this survey was conducted in smaller groups of up to 30 students. The time allotted for filling out the questionnaire was 45 minutes, and students were offered help in terms of additional clarification of certain questions.

Participation in this research study was voluntary. All participants gave their written informed consent to participate in the study by submitting/ signing a form that included information about the research and its aims, methods of handling data, participant rights and data protection, and possible risks. According to the Ethics Code for Researching Children (2003), children older than 14 years can give their independent consent to participate in research studies, but several schools demanded that informed consent must be obtained from their respective parents as well in order to comply with General Data Protection Regulation. Therefore, in these schools, we requested parents to give their written consent for their child to participate in the study. Before filling in the questionnaire, participants were verbally introduced to the aim and objectives of the study, they were informed that their participation was anonymous and voluntary, and that they were free to withdraw at any time point if they wanted to do so. The questionnaire 
vima istraživanja, upućeni u to da je sudjelovanje anonimno i dragovoljno te da mogu odustati kada god požele. Primjenu upitnika proveli su istraživači i posebno educirani suradnici projekta, studenti diplomskog studija Socijalne pedagogije (Edukacijsko-rehabilitacijski fakultet, Sveučilište u Zagrebu).

\section{Instrumenti}

Istraživanje je provedeno u okviru "Pozitivan razvoj adolescenata u Hrvatskoj (PRAG - HR)". Za potrebe navedenog projekta izrađen je instrument koji se sastoji od nekoliko različitih skala iz područja rizičnih ponašanja, internaliziranih simptoma, usredotočene svjesnosti, socijalno-emocionalnih vještina, zadovoljstva obiteljskim životom, vezanosti za školu, otpornosti, obiteljske komunikacije, životnih događaja te od dodatnih pitanja kojima su prikupljeni sociodemografski podaci o sudionicima istraživanja.

Za potrebe ovog rada, kako bi se dobili podaci potrebni za ostvarivanje cilja i kako bi se odgovorilo na postavljene ciljeve , uzeti su u obzir sljedeći instrumenti:

(1) Upitnik o demografskim podacima (izrađen za potrebe projekta) sadrži pitanja kojima su se prikupljali osnovni podaci o ispitanicima kao što su spol, dob, ime škole, vrsta škole, razred i slično.

(2) CTC Upitnik za učenike (Mihić, Novak i Bašić, 2010). Upitnikom se ispituju ponašanja vezana uz školu i odnos prema školi, korištenje interneta, rizično seksualno ponašanje, iskustva vršnjačkog nasilja, zlostavljanja u vezi, igre na sreću, ali i pijenje te korištenje sredstava ovisnosti. Za potrebe ovog istraživanja uzeti su u obzir podaci koji se odnose na iskustvo doživljenog vršnjačkog nasilja "u zadnja 4 tjedna" budući da taj podatak daje jasniju sliku o veličini problema, nego životna prevalencija.

(3) Modificirana verzija Resilience and Youth Development Module (California Department of Education, 1997). Modificirana skala otpornosti i razvoja mladih (Resilience youth development module ili RYDM) mjeri osam vanjskih i šest unutarnjih snaga pozitivnog razvoja. Vanjske su snage visoka očekivanja, brižni odnosi i was administered by researchers and specially trained associates who collaborated on the project (i.e.,) graduate students in the field of Social Pedagogy (Faculty of Education and Rehabilitation Sciences, University of Zagreb).

\section{Research instruments}

The present study was conducted within the framework of the "Positive Development of adolescents in Croatia (PRAG-HR)" project. The research instruments developed for this project consist of several different scales in the area of risk behaviours, internalised symptoms, focused awareness, social-emotional skills, satisfaction with family life, attachment to school, resilience, family communication, life events, and additional questions to collect sociodemographic data on research participants.

The following survey instruments were applied to collect data for the purpose of this paper in correspondence with the pre-set aims of these comprehensive instruments:

(1) Questionnaire on demographic data (developed for the purpose of this project) - questions on basic participant data such as sex, age, name of school, type of school, and grade.

(2) CTC Youth Survey (Mihić, Novak and Bašić, 2010) - questionnaire exploring behaviours related to school and attitude towards school, internet use, risky sexual behaviour, experience of peer violence, abuse in relationships, gambling games, drinking, and drug use. In the present study, we focused on data referring to experiences of peer violence in the past 30 days rather than in the child's lifetime; data from this time frame was useful in order to gain insight into the current situation regarding previously experienced peer violence.

(3) Modified version of the Resilience and Youth Development Module (RYDM; California Department of Education, 1997) - RYDM measures eight external and six internal assets of positive development. The external assets include high expectations, caring relationships and meaningful participation in the family environment, high expectations with respect to prosocial peers and caring relationships in the peer 
smislena uključenost u obiteljsko okruženje, prosocijalni vršnjaci i brižni odnosi u vršnjačkoj skupini te visoka očekivanja, brižni odnosi i smislena uključenost u zajednicu. Unutarnje su snage suradnja i komunikacija, samoučinkovitost, empatija, vještina rješavanja problema, samosvijest te ciljevi i aspiracije. Sudionici istraživanja zamoljeni su da procijene prisutnost pojedinih čimbenika otpornosti u svojem životu. Za svaki od čimbenika otpornosti navedene su tri čestice, odnosno tri tvrdnje. Sudionici su samoprocjenom tvrdnje stupnjevali prema četiri zadana stupnja: "uopće nije istinita", "donekle je istinita", "u većoj mjeri je istinita" te "potpuno je istinita". Za onu tvrdnju koja za njih najviše vrijedi prema stupnju odgovora stavljali su znak " $x$ " u prazan kvadratić određenog stupnja.

\section{Metode obrade podataka}

U svrhu ostvarivanja ciljeva ovog istraživanja sve statističke analize provedene su korištenjem programa SPSS Statistics for Windows, Version 21.0 (IBM, Armonk, NY, USA). Od statističkih metoda i analiza korištena je logistička regresijska analiza.

\section{REZULTATI ISTRAŽIVANJA}

Kada se govori o prevalenciji vršnjačkog nasilja na području Varaždina, u istraživanju je 40,2\% sudionika navelo da je od jedanput do nekoliko puta u zadnjih četiri tjedna svjedočilo vršnjačkom nasilju, dok je $8 \%$ učenika navelo da je tome svjedočilo jednom tjedno ili češće. Ujedno 19,9\% sudionika navelo je da su i sami doživjeli vršnjačko nasilje. Njih 8,6\% sudjelovalo je u tučnjavi jednom ili češće u zadnja četiri tjedna. Istraživanje također pokazuje kako su rezultati za sudionike iz varaždinskih škola ujednačeni s podacima za cjelokupni hrvatski uzorak u istom istraživanju (10 138 mladih iz Zagreba, Pule, Osijeka, Splita i Varaždina) (Laboratorij za prevencijska istraživanja ERF-a, 2019).

\section{Otpornost i vršnjačko nasilje}

Doprinos čimbenika otpornosti u objašnjenju doživljenog vršnjačkog nasilja utvrđen je provedbom logističke regresijske analize. Kao kri- group, as well as high expectations, caring relationships, and meaningful participation in the community. The internal assets include cooperation and communication, self-efficacy, empathy, problem solving skills, self-awareness, and goals and aspirations. Research participants were asked to assess the presence of individual resilience factors in their lives, and three items (i.e.,) claims were provided in correspondence with each of the resilience factors. Based on a self-assessment, the participants graded these claims according to four different criteria: "not true at all", "somewhat true", "true to a great extent", and "completely true". Participants were asked to mark an " $\mathrm{X}$ " next to the claim that was most applicable to them based on the degree of their response.

\section{Data processing methods}

All statistical analyses were performed using SPSS 21.0 (IBM, Armonk, NY, USA). Data collected were analysed using logistic regression analysis.

\section{RESULTS}

In terms of the prevalence of peer violence prevalence in Varaždin, our results show that $40.2 \%$ of participants stated that they had witnessed peer violence once or a few times in the past four weeks, while $8 \%$ of the students stated that they witnessed peer violence once a week or even more. Furthermore, 19.9\% of participants stated they experienced peer violence themselves, while $8.6 \%$ of them participated in a fight more than once in the past four weeks. Research has also shown that the results for the Varaždin participants are in line with data for the entire Croatian sample: in the same research study (10.138 youth from Zagreb, Pula, Osijek, Split, and Varaždin (Laboratorij za prevencijska istraživanja ERF-a, 2019).

\section{Resilience and peer violence}

Logistic regression analysis was used to determine the effect of resilience factors on peer violence. The variable 'peer violence' was considered as the criterion variable: this dichotomous/binary variable consisted of two categories, where 0 indi- 
terijska varijabla određena je varijabla vršnjačko nasilje. Dihotomna/binarna varijabla vršnjačko nasilje sastoji se od dvije kategorije $(0=$ oni koji nisu doživjeli vršnjačko nasilje i $1=$ oni koji su doživjeli jednom, nekoliko puta, jednom tjedno i svaki dan vršnjačko nasilje u zadnja četiri tjedna). Logistička regresijska analiza ima tri preduvjeta za provedbu. Prije svega, uzorak mora biti 10 puta veći od broja zadanih prediktora. U bazi se nalaze podaci za 1647 mladih te je time zadovoljen preduvjet veličine uzorka, uzevši u obzir činjenicu da imamo 20 zadanih prediktora. Nadalje Hosmer and Lemeshow Test (Tablica 1) statistički nije značajan $(\mathrm{p}>0,05)$, što ukazuje na to da su prediktori linearno povezani s vjerojatnošću pojave koja se predviđa (objašnjenje doživljenog vršnjačkog nasilja) te je time zadovoljen drugi preduvjet za provedbu logističke regresijske analize. Također je zadovoljen i posljednji preduvjet koji se odnosi na provjeru multikolinearnosti, odnosno utvrđivanja postoji li previsoka međusobna povezanost među prediktorima. VIF- vrijednosti koje iznose iznad 10 smatraju se problematičnima jer ukazuju na snažnu linearnu povezanost prediktora (Pituch i Stevens, 2016). Provedbom analize uočena je odsutnost multikolinearnosti s obzirom na to da su provedbom analize dobivene VIF-vrijednosti niže od 4,22.

Provedenom logističkom regresijskom analizom na uzorku od 1647 adolescenata na području Varaždinske županije utvrđeno je da odabrani skup prediktora statistički značajno pridonosi objašnjavanju doživljenog vršnjačkog nasilja $\left(\chi^{2}(20)=\right.$ $143,969, \mathrm{p}<0,01)$. Dobiveni Nagelkerke $\mathrm{R}^{2}$ pokazuje da se na temelju spola, dobi, individualnih čimbenika otpornosti (suradnja i komunikacija, samoučinkovitost, empatija, rješavanje problema, samosvijest, ciljevi i aspiracije), čimbenika otpornosti u okruženju vršnjaka (visoka očekivanja prosocijalni vršnjaci, brižni odnosi), čimbenika otpornosti u obiteljskom okruženju (visoka očekivanja, brižni odnosi, smislena uključenost) te čimbenika otpornosti u zajednici (visoka očekivanja, brižni odnosi, smislena uključenost) zajedno može objasniti 13,8\% doživljenog vršnjačkog nasilja barem jedanput u zadnja četiri tjedna. Također na temelju odabranih prediktora točno je klasificirano $80,7 \%$ ispitanika. cated those who did not experience peer violence and 1 indicated those who experienced peer violence once, several times, once a week, and every day in the past four weeks. The logistic regression analysis was performed based on three assumptions. First, the sample had to be ten times bigger than the number of set predictors. In the present study, we collected data on 20 set predictors from 1,647 students, and therefore met the requirements of the sample size assumption. Furthermore, the results of the Hosmer and Lemeshow test showed no statistically significant relationships ( $p>0.05$; Table 1), suggesting that predictors are linearly connected to the probability of the predicted phenomenon (factors associated with previous experiences of peer violence), therefore satisfying the second requirement for the implementation of the regression analysis. Finally, we were also able to verify multicollinearity by determining whether the predictors are highly correlated with one another or not. Variance inflation factor values $>10$ are considered problematic since they suggest strong linear correlation of predictors (Pituch and Stevens, 2016). Our analysis showed the absence of multicollinearity based on variance inflation factor values $<4.22$.

Logistic regression analysis based on a sample of 1,647 adolescents from Varaždin County showed that a select group of predictors played a statistically significant role in explaining previously experienced peer violence $\left(\chi^{2}(20)=143.969, p<0.01\right.$; Table 1): these predictors include sex, cooperation and communication, empathy, high expectations prosocial peers, and caring relationships with peers and in the family environment. Self-efficacy is significant with a $5 \%$ risk $(\mathrm{p}<0.05)$, while all the other mentioned predictors are significant with a risk of $1 \%(p<0.01)$. Sex and empathy have significant positive correlations with previous experience of peer violence, while cooperation and communication, self-efficacy, high expectations - prosocial peers, and caring relationships with peers and in the family environment have a negative correlation with previous experiences of peer violence.

Based on the Nagelkerke $\mathrm{R}^{2}$ value, we found that a combination of predictors can explain $13.8 \%$ of peer review experienced at least once in the last four weeks: the predictors include age, sex, indi- 
Matea Belošević, Martina Ferić, Ivana Mitrić: Čimbenici otpornosti i iskustvo vršnjačkog nasilja / Resilience factors and experience of peer...

Tablica 1. Rezultati binarne logističke regresije s doživljenim vršnjačkim nasiljem među mladima na području Varaždinske županije kao kriterijskom varijablom / Table 1. Binary logistic regression analysis using previous experiences of peer violence among youth in Varaždin County as the criterion variable

\begin{tabular}{|l|l|c|c|c|c|c|c|}
\hline & & \multicolumn{5}{|c|}{ Previous experience of peer violence } \\
\hline & Predictor & $\mathbf{B}$ & $\mathbf{S E}$ & $\mathbf{W a l d}$ & $\mathbf{p}$ & $\mathbf{O R}$ & $\begin{array}{c}\text { Reliability } \\
\text { interval }\end{array}$ \\
\hline & Sex & & & & & & \\
\hline & Age (years) & 0.411 & 0.156 & 6.998 & $\mathbf{0 . 0 0 8}$ & 1.509 & $1.112-2.047$ \\
\hline \multirow{4}{*}{ FACTORS } & Cooperation and communication & -0.454 & 0.133 & 11.68 & $\mathbf{0 . 0 0 1}$ & 0.635 & $0.49-0.824$ \\
\cline { 2 - 8 } & Self-efficacy & -0.332 & 0.148 & 5.028 & $\mathbf{0 . 0 2 5}$ & 0.718 & $0.537-0.959$ \\
\cline { 2 - 8 } & Empathy & 0.377 & 0.113 & 11.197 & $\mathbf{0 . 0 0 1}$ & 1.458 & $1.169-1.819$ \\
\cline { 2 - 8 } & Problem solving & 0.207 & 0.117 & 3.131 & 0.077 & 1.230 & $0.978-1.546$ \\
\cline { 2 - 8 } & Self-awareness & -0.178 & 0.11 & 2.617 & 0.106 & 0.837 & $0.675-1.038$ \\
\cline { 2 - 8 } & Goals and aspirations & 0.005 & 0.12 & 0.002 & 0.964 & 1.005 & $0.795-1.272$ \\
\hline \multirow{5}{*}{ PEERS } & High expectations - Prosocial peers & -0.549 & 0.137 & 16.165 & $<\mathbf{0 . 0 0 1}$ & 0.577 & $0.442-0.755$ \\
\cline { 2 - 8 } & Caring relationships & -0.455 & 0.098 & 21.545 & $<\mathbf{0 . 0 0 1}$ & 0.635 & $0.524-0.769$ \\
\hline \multirow{5}{*}{ COMILY } & High expectations & 0.231 & 0.167 & 1.9 & 0.168 & 1.26 & $0.907-1.749$ \\
\cline { 2 - 8 } & Caring relationships & -0.28 & 0.119 & 5.498 & $\mathbf{0 . 0 1 9}$ & 0.756 & $0.598-0.955$ \\
\cline { 2 - 8 } & Meaningful participation & -0.03 & 0.082 & 0.134 & 0.714 & 0.971 & $0.827-1.139$ \\
\hline & High expectations & 0.068 & 0.166 & 0.167 & 0.682 & 1.07 & $0.773-1.483$ \\
\cline { 2 - 8 } & Caring relationships & -0.018 & 0.157 & 0.013 & 0.908 & 0.982 & $0.723-1.335$ \\
\cline { 2 - 8 } & Meaningful participation & 0.079 & 0.076 & 1.085 & 0.298 & 1.082 & $0.933-1.256$ \\
\cline { 2 - 7 } & Constant & 2.571 & 0.712 & 13.04 & $<0.001$ & 13.078 & \\
\hline
\end{tabular}

Hosmer and Lemeshow test $-\chi^{2}(8)=6.521, p>0.05$; Omnibus tests of model coefficients $-\chi^{2}(20)=143.969, p<0.01$; Nagelkerke $\mathbf{R}^{2}-13.8 \%$

Iz Tablice 1 može se vidjeti kako su statistički značajni prediktori spol, suradnja i komunikacija, samoučinkovitost, empatija, visoka očekivanja - prosocijalni vršnjaci i brižni odnosi od strane vršnjaka te brižni odnosi u obiteljskom okruženju. Samoučinkovitost je značajna uz 5\% rizika ( $\mathrm{p}<$ $0,05)$, dok su svi ostali navedeni prediktori značajni uz $1 \%$ rizika $(\mathrm{p}<0,01)$. Spol i empatija imaju pozitivnu povezanost, dok suradnja i komunikacija, samoučinkovitost, visoka očekivanja - prosocijalni vršnjaci i brižni odnosi od strane vršnjaka te brižni odnosi u obiteljskom okruženju imaju negativnu povezanost s kriterijem (doživljeno vršnjačko nasilje).

U odnosu na demografske varijable rezultati logističke regresije pokazuju kako je doprinos spola značajan i pozitivan te ukazuje na to da je ženski spol u većoj mjeri povezan s doživljenim vršnjačkim nasiljem (Exp (B)), odnosno ODDS RATIO pokazuje da je učinak ženskog spola čak 1,50 puta vjerojatniji u odnosu na muški spol. Pojedinačno gledano, osim ženskog spola prediktor koji povećava vjerojatnost doživljenog vršnjačkog nasilja jest empatija. S druge strane prediktori koji vidual resilience factors (cooperation and communication, self-efficacy, empathy, problem solving, self-awareness, goals and aspirations), resilience factors in the peer environment (high expectations - prosocial peers, caring relationships), resilience factors in the family environment (high expectations, caring relationships, meaningful participation), as well as resilience factors in the community (high expectations, caring relationships, meaningful participation). Moreover, based on select group of predictors identified $80.7 \%$ of participants were classified correctly.

Considering the demographic variables, sex, especially the female sex, had a significant positive association with previously experienced peer violence: the effect of the female sex was 1.5 times higher than that of the male sex (see Exp (B) and OR in Table 1). Individually, besides the female sex, the predictor that increases the probability of experiencing peer violence is empathy. On the other hand, the predictors that reduce the probability of experiencing peer violence are cooperation and communication, self-efficacy, high expecta- 


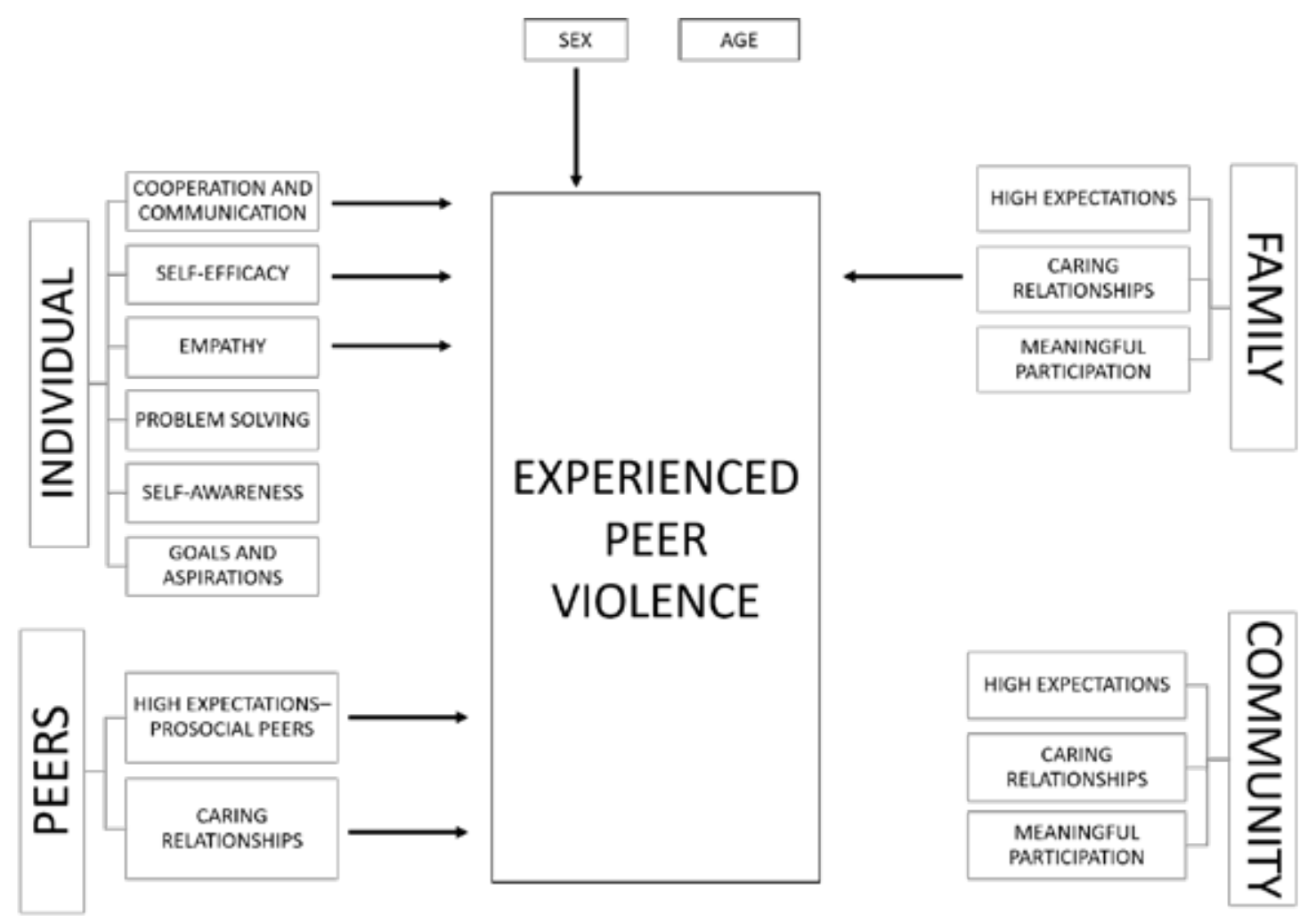

Slika 1. Grafički prikaz rezultata modela doživljenog vršnjačkog nasilja / Figure 1. Graphical representation of role of resilience factors on peer violence

smanjuju vjerojatnost doživljenog vršnjačkog nasilja jesu suradnja i komunikacija, samoučinkovitost, visoka očekivanja - prosocijalni vršnjaci i brižni odnosi od strane vršnjaka te brižni odnosi u obiteljskom okruženju

Također je vidljivo kako vještina rješavanja problema, samosvijest, ciljevi i aspiracije, visoka očekivanja i smislena uključenost u obiteljskom okruženju te visoka očekivanja, brižni odnosi i smislena uključenost u zajednicu nisu značajni prediktori doživljenog vršnjačkog nasilja $(p>0,05)$. Predloženi model grafički je prikazan na Slici 1. Značajni prediktori doživljenog vršnjačkog nasilja označeni su strelicama.

\section{RASPRAVA}

Ovim istraživanjem želio se utvrditi doprinos demografskih varijabli, individualnih čimbenika otpornosti te čimbenika otpornosti u okruženju vršnjaka, obiteljskom okruženju i zajednici u tions - prosocial peers, and caring relationships with peers and in the family environment.

Furthermore, problem solving skills, self-awareness, goals and aspirations, high expectations and meaningful participation in the family environment, as well as high expectations, caring relationships, and meaningful participation in the community had no effect on previously experienced peer violence $(\mathrm{p}>0.05)$. Figure 1 depicts a graphical overview of the predictors of previously experienced peer violence (significant predictors are marked with arrows).

\section{DISCUSSION}

The present study aimed to confirm the role played by a combination of factors, including demographic variables, individual resilience factors, as well as resilience factors in the peer environment, family environment, and community, in explaining peer violence experienced by youth in 
objašnjenju doživljenog vršnjačkog nasilja od strane mladih na području Varaždinske županije. Slijedom toga provedena je logistička regresijska analiza. Nalazi dobiveni ovim istraživanjem potvrđuju doprinos ispitivanih čimbenika u objašnjenju doživljenog vršnjačkog nasilja, međutim oni objašnjavaju samo $13,8 \%$ doživljenog vršnjačkog nasilja barem jednom u zadnja četiri tjedna. Rezultati pokazuju da je vjerojatnije da će djevojke te mladi koje izvještavaju o većoj razini empatije doživjeti vršnjačko nasilje, dok je manje vjerojatno da će oni koji izvještavaju o većoj razini suradnje i komunikacije, samoučinkovitosti, oni koji se druže s prosocijalnim vršnjacima i imaju brižne odnose s njima te oni koji imaju iskustvo brižnih odnosa u obitelji, doživjeti vršnjačko nasilje. Usto potrebno je dodatno objasniti što pridonosi visokom postotku (86\%) doživljenog vršnjačkog nasilja te navedeno može biti cilj budućih istraživanja.

U odnosu na spol ispitanika, rezultat dobiven ovim istraživanjem ukazuje na to da je ženski spol prediktor doživljenog vršnjačkog nasilja. U ovom istraživanju sudionici su bili ispitivani općenito o doživljenom vršnjačkom nasilju (npr. fizički napad, ismijavanje, isključivanje...) te nisu zasebno ispitivani oblici doživljenog vršnjačkog nasilja. Rezultati drugih istraživanja u odnosu na međuvršnjačko nasilje pokazuju da djevojčice češće koriste verbalnu i indirektnu agresiju i češće su nasilne prema djevojčicama, a dječaci češće koriste tjelesnu agresiju i podjednako su nasilni prema dječacima i djevojčicama (Bilić, Buljan Flander i Hrpka, 2012). Nadalje istraživanje provedeno među adolescentima u školama u 40 zemalja ukazuje na prevalenciju bilo koje vrste umiješanosti u vršnjačko nasilje (kao žrtve, počinitelja ili oboje) u rasponu između $8,6 \%$ i $45,2 \%$ za dječake i između $4,8 \%$ i $35,8 \%$ za djevojčice (Craig i sur., 2009). Međutim pojedina istraživanja ipak sugeriraju da su osobe ženskog spola osjetljivije na učinke nasilja od muškaraca (Barker i sur., 2008; Klomek i sur., 2009) te kako su djevojke u većem riziku od nasilja u vezama, seksualnog nasilja i nasilja od strane intimnih partnera (WHO, 2015).

U odnosu na čimbenike otpornosti, kao što je već istaknuto, unutarnje prednosti kao i vanjski
Varaždin County. We performed a logistic regression analysis and showed that predictors with a statistically significant association with peer violence explained only $13.8 \%$ of the peer violence experienced by participants at least once in the last four weeks. Our findings show that girls and youth with greater levels of empathy are more likely to experience peer violence, while those who report greater levels of cooperation and communication, self-efficacy, those who spend time with prosocial peers, as well as have caring relationships with peers and family members are less likely to experience peer violence. Further studies are required to gain a better understanding of the factors that contribute to explaining the rest of the $86 \%$ of peer violence experienced by youth.

In terms of sex, the results of this study suggest that female sex is a predictor of peer violence. In this study, participants were asked about the peer violence they experienced (e.g., physical attacks, being made fun of, exclusion from peers), but the types of peer violence experienced were not examined separately. The findings of previous studies on peer violence suggest that girls are more likely to use verbal and indirect aggression, and are more violent towards girls, while boys are more likely to use physical aggression and are equally violent towards boys and girls (Bilić, Buljan Flander and Hrpka, 2012). Furthermore, research on adolescents conducted in schools across 40 countries highlighted that the prevalence of any type of involvement in peer violence (as victims, perpetrators, or both) ranged from $8.6-45.2 \%$ for boys and 4.8-35.8\% for girls (Craig et al., 2009). However, other studies have suggested that women are more sensitive to the effects of violence than men (Barker et al., 2008; Klomek et al., 2009), and girls face a greater risk of violence in relationships, including sexual violence and violence from their intimate partners (WHO, 2015).

In terms of resilience factors, we emphasise that both internal and external assets and resources in the environment can directly reduce the probability of negative behaviour such as violence (Sun and Shek, 2012). In a study involving 2,291 school students $\left(7^{\text {th }}, 8^{\text {th }}\right.$, and $9^{\text {th }}$ graders $)$ in Canada, researchers found that students with fewer "resiliency strengths" were twice as likely to be 
resursi u okruženjima mogu izravno umanjiti vjerojatnost negativnog ponašanja poput nasilja (Sun i Shek, 2012). U istraživanju u kojem je sudjelovao 2291 učenik 7, 8. i 9. razreda u Kanadi istraživači su otkrili da je za učenike s manje "snaga otpornosti" više nego dvostruko vjerojatnije da će biti žrtve nasilja (Hinduja i Patchin, 2017). U odnosu na suradnju i komunikaciju dobiveni rezultati u skladu su s drugim istraživanjima. Istraživanja pokazuju kako je upravo učinkovita komunikacija u odnosima s vršnjacima zaštitni čimbenik protiv viktimizacije (Blood i Blood, 2004). Sofronoff, Dark i Stone (2011) izvještavaju kako su vulnerabilni studenti laka i česta meta za vršnjačku viktimizaciju. Nadalje niska razina samoučinkovitosti identificirana je u ovom, ali i u drugim istraživanjima kao prediktor vršnjačkog nasilja (Ali, Swahn i Sterling, 2011; Jagers, Sydnor, Mouttapa i Flay, 2007). Tako Tobias i Chapanar (2016) ističu kako su osobe s višim rezultatima samoučinkovitosti suštinski otpornije na vršnjačko nasilje. Hirschtritt i suradnici (2015) navode kako čimbenici individualne otpornosti, poput samoučinkovitosti i samosvijesti, mogu biti najučinkovitiji u suzbijanju verbalnog vršnjačkog nasilja, odnosno nefizičkih oblika agresije. U odnosu na empatiju istraživanja nisu u potpunosti dosljedna. Pojedina istraživanja pokazuju kako je empatija zaštitni čimbenik za vršnjačko nasilje (Zych, Farrington i Ttofi, 2019; Zych, Viejo, Vila i Farrington, 2019). Međutim rezultat ovog istraživanja, kao i istraživanje koje su proveli Espejo-Siles i suradnici (2020) na uzorku od 871 učenika u dobi od 10 do 17 godina, pokazuje kako visoka razina empatije nije zaštitni čimbenik od vršnjačkog nasilja. Malti, Perren i Buchmann (2010) ističu kako viktimizirana djeca pokazuju više empatije jer su posebno osjetljiva na emocionalne posljedice prijestupa. Navedeno neizravno podupiru Menesini, Sanchez, Fonzi, Ortega, Costabile i LoFeudo (2003) koji ističu da žrtve nasilja pokazuju ravnodušnost i ponos prema drugim žrtvama rjeđe nego što to čine nasilnici. Nadalje Tone i Tully (2014) iznose pretpostavku kako empatija u određenim okolnostima može predstavljati rizik za razvoj internaliziranih problema u ponašanju. Navedeni rezultati istraživanja sugeriraju kako pojedini čimbenici otpornosti u određenim kontekstima nisu nužno zaštita victims of bullying (Hinduja and Patchin, 2017). Regarding cooperation and communication, our results correspond to previous findings. Efficient communication in relationships with peers can act as a protective factor against victimisation (Blood and Blood, 2004). Sofronoff, Dark and Stone (2011) reported that vulnerable students are an easy and frequent target for peer victimisation. Furthermore, low levels of self-efficacy has been identified as a predictor of peer violence. Hence, Tobias and Chapanar (2016) stated that individuals with higher levels of self-efficacy are essentially more resilient to peer violence. Hirschtritt, Ordóñez, Rico and Lewinn (2015) also stated that factors of individual resilience, such as self-efficacy or self-awareness, can be the most successful factors in the prevention of verbal peer violence (i.e.,) non-physical forms of aggression. Although some studies show that empathy is a protective factor for peer violence (Zych, Farrington and Ttofi, 2019; Zych, Viejo, Vila and Farrington, 2019), these results are not consistent. However, the results of the present study, as well as another study Espejo-Siles, Zych, Farrington and Llorent (2020) involving a sample of 871 students, aged 10 to 17 years, show that high levels of empathy do not protect adolescents from peer violence. Malti, Perren and Buchmann (2010) emphasised that victimised children show more empathy because they are particularly sensitive to the emotional consequences of the offence. These results are indirectly supported by Menesini, Sanchez, Fonzi, Ortega, Costabile and Lo Feudo (2003), who emphasised that victims of violence attribute indifference and pride towards other victims less often than the bullies. Furthermore, Tone and Tully (2014) assumed that empathy in certain circumstances can present a risk for developing internalised behavioural problems. These results suggest that individual resilience factors in certain contexts are not necessarily protective in nature, and therefore may present a challenge for future researchers. It is important to gain insights about the conditions and/or contexts in which protective factors/mechanisms identified in many research studies can become a risk factor instead.

In terms of relationships with peers, it is emphasised that the lack of social ties and hav- 
te samim time predstavljaju izazov, ali i smjer za buduća istraživanja. S obzirom na to bilo bi važno steći uvid u kojim uvjetima i/ili kontekstima neki od čimbenika/mehanizama, koji su u mnogim istraživanjima identificirani kao zaštitni, prestanu biti zaštita i postaju rizik.

Kada se govori o odnosima s vršnjacima, ističe se kako je nedostatak socijalnih veza i povezanost $\mathrm{s}$ asocijalnim vršnjacima snažno povezana $\mathrm{s}$ nasiljem među mladima (Lipsey i Derzon, 1998, prema WHO, 2015). Ovo istraživanje potvrdilo je manju vjerojatnost da će mladi koji percipiraju svoje vršnjake kao prosocijalne i one koji postavljaju visoka očekivanja te imaju brižne odnose s njima doživjeti vršnjačko nasilje. Navedene rezultate potvrđuju i druga istraživanja (Kochel i sur., 2012; Košir i sur., 2019; Rudolph i sur., 2014; Lin, Chen, Tian i Zhang, 2018). Također važnost odnosa s vršnjacima dodatno ističe nalaz metaanalize 153 studije koju su proveli Cook i suradnici (2010) koja je pokazala kako je status vršnjaka imao najveću veličinu učinka u odnosu na viktimizaciju i kao takav bio najsnažniji individualni prediktor vršnjačke viktimizacije. Osim brižnih odnosa od strane vršnjaka u ovom su radu brižni odnosi u obiteljskom okruženju pozitivno povezani s doživljenim vršnjačkim nasiljem. Druga istraživanja ističu upravo kako pozitivno obiteljsko okruženje može poslužiti u ublažavanju stresa omogućavajući adolescentima da se učinkovitije nose s emocionalnim posljedicama nasilja (Bowes i sur., 2010). Naime Bowes, Maughan, Caspi, Moffitt i Arseneault (2010) sugeriraju da, iako su brižni obiteljski odnosi važni za svu djecu, oni mogu biti posebno korisni za djecu koja su doživjela vršnjačko nasilje. Na primjer longitudinalno istraživanje u Škotskoj u kojem je sudjelovalo 3136 mladih u dobi od 12 do 14 godina pokazalo je da zlostavljani mladi s većim samopoštovanjem, više socijalne povezanosti i boljim obiteljskim odnosima pokazuju emocionalnu otpornost ( $\mathrm{tj}$. manje depresivnog raspoloženja od očekivanog) i ponašajnu otpornost ( $\mathrm{tj}$. bili su manje delinkventni od očekivanoga) (Sapouna i Wolke, 2013). Slično tome topli obiteljski odnosi, kao i pozitivna atmosfera u domu, bili su značajno povezani s otpornošću na doživljeno zlostavljanje u longitudinalnom istraživanju u Velikoj Britaniji ing antisocial peers is strongly correlated with violence among youth (Lipsey and Derzon, 1998, according to WHO, 2015). A number of studies have confirmed that youth who perceive their peers as prosocial and those who set high expectations and have caring relationships with them are lee likely to experience peer violence (Kochel et al., 2012; Košir et al., 2019; Rudolph et al., 2014; Lin, Chen, Tian and Zhang, 2018). The importance of relationships with peers has received additional support based on the findings of a meta-analysis involving 153 studies (Cook, Williams, Guerra, Kim and Sadek (2010): this meta-analysis showed that peer status had the largest effect size with respect to being a victim of bullying and was the strongest individual predictor of peer victimisation. Apart from highlighting the importance of having caring relationships with peers, the present study also emphasised on the positive correlation between having caring relationships in the family environment and the reduced probability of experiencing peer violence. A positive family environment can help alleviate stress, thus allowing the adolescents to handle the emotional consequences of violence more efficiently (Bowes et al., 2010) suggested that although caring family relationships are important for all children, they can be particularly beneficial for children who experience peer violence. For example, a longitudinal study carried out in Scotland involving 3,136 youth, aged 12 to 14 years, showed that abused youth with greater self-respect, more social connections, and better family relationships showed emotional (i.e., they exhibited fewer symptoms of depression than expected) and behavioural resilience (i.e., they showed fewer signs of delinquent behaviour than expected) (Sapouna and Wolke, 2013). Similarly, affectionate family relationships, as well as a positive home atmosphere were both significantly correlated with resilience among adolescents who experienced violence; these results were determined in a longitudinal research study in the United Kingdom that involved 1,116 pairs of twins aged 10 to 12 years (Bowes, Maughan, Caspi, Moffitt and Arseneault, 2010). It is important to emphasise that individual, family, and societal factors can serve as protective factors for adolescents who experience peer violence (Tobias and Chapanar, 2016). 
u kojem je sudjelovalo 1116 parova blizanaca u dobi između 10 i 12 godina (Bowes, Maughan, Caspi, Moffitt i Arseneault, 2010). Potrebno je istaknuti kako individualni, obiteljski i društveni čimbenici mogu djelovati kao zaštitni čimbenici za adolescente koji su doživjeli vršnjačko nasilje (Tobias i Chapanar, 2016).

\section{OGRANIČENJA}

Ovo istraživanje ima određena ograničenja. Naime kao jedini izvor informacija za mjerenje vršnjačkog nasilja korišten je samoiskaz adolescenata. Potrebno je imati na umu kako nisu sve žrtve nasilja spremne prijaviti svoja iskustva čak ni u povjerljivom i anonimnom istraživanju jer brojne žrtve nasilja pate u tišini. Istraživanje u engleskim školama pokazalo je da $30 \%$ djece koja su doživjela nasilje u školskom okruženju nikome nisu ispričala svoja iskustva (Smith i Shu, 2000). Primjerice doživljeno vršnjačko nasilje moglo je biti nedovoljno prijavljivano zbog tendencije pojedinaca da daju društveno poželjne odgovore (Van de Mortel, 2008). Također pojedini autori ističu da su podaci koji proizlaze iz sjećanja pojedinaca na prošlost u svojoj osnovi nepouzdani zbog tendencije da se pogrešno prikažu ili iskrive činjenice iz prethodnog vremenskog razdoblja (Hinduja i Patchin, 2017). U ovom se istraživanju navedenom problemu nastojalo doskočiti tako da se tražilo od učenika da izvještavaju samo o relativno nedavnim iskustvima doživljenog vršnjačkog nasilja (u zadnja četiri tjedna). Nadalje s obzirom na to da je uzorak bio kvotni te čini oko $30 \%$ populacije varaždinskih srednjoškolaca koji u omjeru zadanih kriterija (tip srednjoškolskog programa, razred, obrazovni program) oslikava populaciju srednjoškolaca na području Varaždinske županije, rezultati se ne mogu generalizirati za cjelokupnu populaciju srednjoškolaca. Buduća istraživanja trebala bi obuhvatiti reprezentativan uzorak koji bi omogućio generalizaciju zaključaka za populaciju srednjoškolaca. Usto rezultati provedene logističke regresijske analize pokazuju kako je na temelju odabranih prediktora točno klasificirano $80,7 \%$ ispitanika. Međutim potrebno je imati na umu kako za 19,7\% ispitanika model ne odgovara, odnosno da temeljem odabranih prediktora nije točno klasificirano $19,7 \%$ ispitanika.

\section{LIMITATIONS}

The results of the present study must be considered in the light of certain limitations. The main source of information regarding victimisation was self-reports from the participants. We must bear in mind that not all victims of violence are ready to report their experiences, even in confidential and anonymous research studies, because many victims of violence often choose to suffer in silence. Research conducted in British schools has shown that $30 \%$ of children who experienced violence in the school environment did not share their experiences with anyone (Smith and Shu, 2000). Experiences of peer violence can be under-reported due to an individual's tendencies to always provide socially acceptable answers (Van de Mortel, 2008). Furthermore, other studies have emphasised that data stemming from an individual's recollection about the past is inherently unreliable due to the tendency to misrepresent or distort facts from an earlier time period (Hinduja and Patchin, 2017).

In the present study, we attempted to overcome that threat by asking the students to report only on recent experiences of peer violence (in the past 30 days). Furthermore, given the fact it was a quota sample accounting for approximately $30 \%$ of the high school student population in Varaždin, which reflects the high school population in the entire Varaždin County based on the set criteria (type of high school education, grade, education program), the results cannot be generalised to the entire population of high school students in Croatia. Future research should have a representative sample that would allow for generalisation of conclusions to the entire population of high-school students. In addition, the logistic regression results showed that, based on the selected predictors, $80.7 \%$ of the participants were correctly classified. It should be noted that for $19.3 \%$ of the participants the model did not fit (i.e.,) based on the selected predictors, $19.3 \%$ of the participants were misclassified

\section{CONCLUSION}

The aim of this paper is to determine the contribution of demographic variables, individual resilience factors, and resilience factors in the peer environment, family environment, and com- 


\section{ZAKLJUС̆AK}

Cilj ovog istraživanja bio je utvrditi doprinos demografskih varijabli, individualnih čimbenika otpornosti i čimbenika otpornosti u okruženju vršnjaka, obiteljskom okruženju i u zajednici u objašnjenju doživljenog vršnjačkog nasilja od strane mladih na području Varaždinske županije. Provedenom logističkom regresijskom analizom utvrđeno je da se na temelju spola, dobi, individualnih čimbenika otpornosti (suradnja i komunikacija, samoučinkovitost, empatija, rješavanje problema, samosvijest, ciljevi i aspiracije), čimbenika otpornosti u okruženju vršnjaka (visoka očekivanja - prosocijalni vršnjaci, brižni odnosi), čimbenika otpornosti u obiteljskom okruženju (visoka očekivanja, brižni odnosi, smislena uključenost) te čimbenika otpornosti u zajednici (visoka očekivanja, brižni odnosi, smislena uključenost) zajedno može objasniti 13,8\% doživljenog vršnjačkog nasilja barem jedanput $u$ posljednja četiri tjedna. Prediktori koji povećavaju vjerojatnost doživljenog vršnjačkog nasilja jesu ženski spol i empatija. S druge strane prediktori koji smanjuju vjerojatnost doživljenog vršnjačkog nasilja jesu suradnja i komunikacija, samoučinkovitost, visoka očekivanja - prosocijalni vršnjaci te brižni odnosi od strane vršnjaka i u obiteljskom okruženju. Dobiveni rezultati iznimno su vrijedni jer pokazuju na koje se čimbenike otpornosti potrebno usmjeriti prilikom razvoja i implementacije preventivnih programa usmjerenih na prevenciju vršnjačkog nasilja.

Naime ovaj rad ima za svrhu pridonijeti planiranju znanstveno utemeljenih intervencija za promociju pozitivnog razvoja/prevenciju rizičnih ponašanja mladih. S obzirom na cilj i svrhu ovaj rad predstavlja sveobuhvatnu sliku otpornosti mladih i vršnjačkog nasilja na području Varaždinske županije. Prema spoznajama autorica na području Varaždinske županije do sada nisu provođena istraživanja kojima bi se stekao uvid u otpornost mladih, ali ni u odnosu na prevalenciju vršnjačkog nasilja među srednjoškolcima. Općenito, rezultati istraživanja PRAG- HR pokazuju kako su u odnosu na prevalenciju vršnjačkog nasilja rezultati za sudionike iz varaždinskih škola ujednačeni s podacima za cjelokupni hrvatski uzorak u istom istraživanju (10 138 mladih iz Zagreba, Pule, Osijeka, Splita i Varaždina) (Laboratorij za prevencijska istraživa- munity in explaining experiences of peer violence among youth from Varaždin County. The data were analysed using logistic regression analysis, which showed that $13.8 \%$ of peer violence experienced at least once in the last four weeks. Experiences of peer violence were significantly associated with a combination of predictors, including sex, age, individual resilience factors (cooperation and communication, self-efficacy, empathy, problem solving, self-awareness, goals and aspirations), resilience factors in the peer environment (high expectations - prosocial peers, caring relationships), resilience factors in the family environment (high expectations, caring relationships, meaningful participation), as well as resilience factors in the community (high expectations, caring relationships, meaningful participation). Predictors that increased the probability of experiencing peer violence were female sex and empathy, while cooperation and communication, self-efficacy, high expectations prosocial peers, and caring relationships with peers and in the family environment reduce the probability of experiencing peer violence. Our findings are valuable because they highlight resilience factors that need to be considered when developing and implementing programs to prevent peer violence.

The purpose of this paper is to contribute to the planning of evidence-based interventions in the field of positive youth development promotion and youth risk behaviour prevention. Considering the goal and purpose, this paper presents a comprehensive picture of youth resilience and peer violence in Varaždin County. As far as we know, this is the first study attempting to gain insights on youth resilience in Varaždin County, especially with respect to the prevalence of peer violence among high school students. In general, the results of the PRAG HR survey showed that, in terms of the prevalence of peer violence, the results obtained for participants from Varaždin are consistent with the data for the entire Croatian sample in the same research study (10.138 youth from Zagreb, Pula, Osijek, Split and Varaždin) (Laboratorij za prevencijska istraživanja ERF -a, 2019). Moreover, as far as we know, there are no research studies addressing how individual and resilience factors in the peer environment, family environment, and community contribute to explaining peer violence, both in Varaždin County 
nja ERF-a, 2019). Nadalje na razini Hrvatske, ali ni na području Varaždinske županije, prema spoznajama autorica do sada nije bilo istraživanja koja su nastojala objasniti kako individualni čimbenici otpornosti i čimbenici otpornosti u okruženju vršnjaka, obiteljskom okruženju i u zajednici pridonose objašnjenju doživljenog vršnjačkog nasilja. Stoga je istraživanje predstavljeno u ovom radu jedinstveno u odnosu na cilj istraživanja za područje Varaždinske županije, ali i Hrvatske i šire. U konačnici, potrebno je nastaviti istraživati navedene koncepte $\mathrm{u}$ hrvatskom kontekstu kako bismo mogli usmjeriti sveobuhvatne napore u prevenciju vršnjačkog nasilja temeljene na procijenjenim potrebama mladih.

Smanjenje vršnjačkog nasilja može značajno pridonijeti pozitivnom i zdravom razvoju mladih. Kreiranjem i provođenjem preventivnih intervencija koje imaju uporište u teorijskom okviru koncepta otpornosti pojačavaju se zaštitni čimbenici koji pomažu mladima prevladati štetne posljedice rizika. Nadalje važna komponenta napora usmjerenih na prevenciju vršnjačkog nasilja jest podizanje svijesti o navedenom problemu i među kreatorima programa i politika. Nasilje među mladima nije jednostavan problem s lakim i jednostavnim rješenjima. Međutim znatna su unaprjeđenja u području prevencijske prakse moguća ukoliko postoji politička volja ključnih ljudi/donositelja odluka za sustavno ulaganje u praksu temeljenu na dokazima u području prevencije nasilja. Osim što nasilje među mladima rezultira znatno povećanim troškovima zdravstvene i socijalne skrbi te pravosuđa, pridonosi i smanjenju produktivnosti i vrijednosti imovine na područjima gdje se javlja te općenito unazađuje društvo. Promocija pozitivnog razvoja mladih, jačanje njihove otpornosti te, posljedično, prevencija uključivanja mladih u rizična ponašanja zadaća je svakog društva. Istraživanja poput ovog mogu dati smjernice za kreiranje (socijalnih) politika i znanstveno utemeljenih preventivnih intervencija koje društvu mogu pomoći da ispuni tu svoju zadaću. and in Croatia. Therefore, the research presented in this paper are unique in terms of the aim of the research study for the area of Varaždin County, but also for Croatia and beyond. Finally, there is a need to further explore these concepts in the Croatian context so that we can focus on developing comprehensive peer violence prevention efforts based on the needs of young people.

Reducing peer violence can contribute significantly to the positive and healthy development of youth. Creation and implementation of preventive interventions founded in the theoretical framework of the resilience concept strengthens protective factors that help youth overcome adverse consequences of risks. Furthermore, if an individual experiences peer violence, it does not necessarily mean that they will experience negative developmental outcomes, because according to the resilience theory, challenging/negative experiences can contribute to individual resilience. This is especially important in the context of peer violence prevention.

In addition, another important aspect of preventing peer violence is raising awareness about this problem among program and policy makers. Youth violence is not a simple problem with easy and simple solutions. However, significant improvements can be achieved with prevention practices if there is political will to do so. A strong case for key stakeholders/decision makers to continuously invest in evidence-based practices in the field of violence prevention is the fact that youth violence results in significantly increased healthcare, social care, and judiciary costs. Moreover, youth violence contributes to reduced productivity and asset values in areas where it occurs, and in general, leads to the deterioration of society. Every society has a task to promote positive development for youth, bolster resilience, and consequently, prevent risk behaviours in youth. Therefore, our study can provide guidelines for social policy making and scientifically-based preventive interventions that can help our society fulfil this mission. 
Matea Belošević, Martina Ferić, Ivana Mitrić: Čimbenici otpornosti i iskustvo vršnjačkog nasilja / Resilience factors and experience of peer...

\section{REFERENCES}

Ali, B., Swahn, M. H. and Sterling, K. L. (2011). Attitudes about violence and involvement in peer violence among youth: Findings from a high-risk community. Journal of Urban Health, 88(6), 1158-1174. doi:10.1007/s11524011-9601-6

Anthony, E. J. (1987). Risk, vulnerability and resilience: An overview. In: E. J. Anthony and B. J. Cohler (Eds.). The invulnerable child (str. 3-48). New York: Guilford Press.

Arseneault, L., Bowes, L., Caspi, A., Maughan, B. and Moffitt, T. (2010). Families promote emotional and behavioural resilience to bullying: Evidence of an environmental effect. Journal of Child Psychology and Psychiatry, 51(7), 809-817. doi:10.1111/j.1469-7610.2010.02216.x

Barnová, S., and Tamášová, V. (2018). Risk and protective factors in the life of youth in relation to resilience. Psychology and Pathopsychology of Child, 52(1), 50-59. doi:10.2478/papd-2018-0001

Bašić, J. and Ferić, M. (2004). Djeca i mladi u riziku: rizična ponašanja. In: J. Bašić, N. Koller-Trbović, N. and S. Uzelac (Eds.). Poremećaji u ponašanju i rizična ponašanja: pristupi i pojmovna određenja (str. 57-72). Zagreb: Edukacijsko-rehabilitacijski fakultet Sveučilišta u Zagrebu.

Bašić, J. (2009). Teorije prevencije: prevencija poremećaja u ponašanju i rizičnih ponašanja djece i mladih. Zagreb: Školska knjiga.

Belošević, M. and Ferić, M. (2020): Čimbenici individualne otpornosti i zadovoljstvo obiteljskim životom: percepcija srednjoškolaca grada Zagreba. Hrvatska revija za rehabilitacijska istraživanja, 56(1), 73-84. doi:10.31299/hrri.56.1.6

Benson, P. L. (2003). Developmental assets and asset-building community: Conceptual and empirical foundations. In: R. M. Lerner and P.L. Benson (Eds.). Developmental assets and asset-building communities: Implications for research, policy, and practice (str. 19-43). Norwell: Kluwer Academic. doi:10.1007/978-1-4615-0091-9_2

Benson, P. L., Scales, P. C., Hamilton, S. F. and Sesma, A. (2007). Positive Youth Development: Theory, Research, and Applications. In: R. M. Lerner (Eds.). Handbook of Child Psychology (pp. 894-941). New York: John Wiley and Sons, Inc. doi:10.1002/9780470147658.chpsy0116

Berc, G. (2012). Obiteljska otpornost - teorija i primjena koncepta u socijalnom radu. Ljetopis socijalnog rada, 19(1), 1-24.

Bilić, V., Buljan Flander, G., Hrpka, H. (2012). Nasilje nad djecom i među djecom. Zagreb: Naklada Slap.

Blakemore, S. J. and Mills, K. L. (2014). Is adolescence a sensitive period for socio-cultural processing? Annual Review of Psychology, 65, 187-207. doi: 10.1146/annurev-psych-010213-115202

Blood, G. W. and Blood, I. M. (2004). Bullying in adolescents who stutter: Communicative competence and self-esteem. Contemporary Issues in Communication Science and Disorders, 31(Spring), 69-79. doi:10.1044/cicsd_31_s_69

Bollmer, J. M., Milich, R., Harris, M. J. and Maras, M. A. (2005). A Friend in Need: The Role of Friendship Quality as a Protective Factor in Peer Victimization and Bullying. Journal of Interpersonal Violence, 20(6), 701-712. doi:10.1177/0886260504272897

Bowes, L., Maughan, B., Caspi, A., Moffitt, T. E. and Arseneault, L. (2010). Families promote emotional and behavioural resilience to bullying: Evidence of an environmental effect. Journal of Child Psychology and Psychiatry, 51(7), 809-817.

Broidy, L., Cauffman, E., Espelage, D. L., Mazerolle, P. and Piquero, A. (2003). Sex differences in empathy and its relation to juvenile offending. Violence and Victims, 18(5), 503-516. https://doi.org/10.1891/088667003780928143

Buchanan, A. (2014). Risk and protective factors in child development and the development of resilience. Open Journal of Social Sciences, 2, 244-249. http://dx.doi.org/10.4236/jss.2014.24025

Cambron, C., Catalano, R. F. and Hawkins, J. D. (2019). The social development model. In: D. P. Farrington, L. Kazemian, A. R. Piquero (Eds.). The Oxford handbook of developmental and life-course criminology (str. 224247). New York: Oxford University Press. 
Capak, K. (2020). Istraživanje o zdravstvenom ponašanju učenika - HBSC 2017/2018. Zagreb: Hrvatski zavod za javno zdravstvo.

Cheung, C. K., Lee, T. Y., Kwong, W. M., and Busiol, D. (2015). Review of the relationships between resilience and positive youth development. In: T. Y. Lee, D. T. L. Shek, and R. C. F. Sun (Eds). Quality of life in Asia: Vol. 7. Student well-being in Chinese adolescents in Hong Kong: Theory, intervention and research (str. 113-126). Springer Science + Business Media. https://doi.org/10.1007/978-981-287-582-2_10

Constantine, N. A. and Benard, B. (2001). California Healthy Kids Survey Resilience Assessment Module: Technical Report. Berkeley, CA: Public Health Institute.

Cook, C. R., Williams, K. R., Guerra, N. G., Kim, T. E. and Sadek, S. (2010). Predictors of bullying and victimization in childhood and adolescence: A meta-analytic investigation. School Psychology Quarterly, 5(2), 65-83.

Corboz, J., Hemat, O., Siddiq, W. and Jewkes, R. (2018). Children's peer violence perpetration and victimization: Prevalence and associated factors among school children in Afghanistan. Plos One, 13(2). doi:10.1371/journal. pone. 0192768

Craig, W., Harel-Fisch, Y., Fogel-Grinvald, H., Dostaler, S., Hetland, J., Simons-Morton, B. and Pickett, W. (2009). A cross-national profile of bullying and victimization among adolescents in 40 countries. International Journal of Public Health, 54(2), 216-224. https://doi.org/10.1007/s00038-009-5413-9

Damon, W. (2004). What is positive youth development? Annals of the American Academy of Political and Social Science, 591(1), 13-24. doi:10.1177/0002716203260092

De Bolle, M. and Tackett, J. L. (2013). Anchoring bullying and victimization in children within a five-factor modelbased person-centred framework. Eur J Personal, 27(3), 280-289. https://doi.org/10.1002/per.1901.

De Bruyn, E. H., Cillessen, A. H. N. and Wissink, I. B. (2010). Associations of peer acceptance and perceived popularity with bullying and victimization in early adolescence. J Early Adolesc, 30(4), 543-566. https://doi. org/10.1177/0272431609340517

Espejo-Siles, R., Zych, I., Farrington, D. P. and Llorent, V. J. (2020). Moral disengagement, victimization, empathy, social and emotional competencies as predictors of violence in children and adolescents. Children and Youth Services Review, 118, 105337. doi:10.1016/j.childyouth.2020.105337

Etički kodeks istraživanja s djecom (2003). Vijeće za djecu Vlade RH, Državni zavod za zaštitu obitelji, materinstva i mladeži, Zagreb.

Forrest-Bank, S. S., Nicotera, N., Anthony, E. K., and Jenson, J. M. (2015). Finding their Way: Perceptions of risk, resilience, and positive youth development among adolescents and young adults from public housing neighborhoods. Children and Youth Services Review, 55, 147-158. doi:10.1016/j.childyouth.2015.05.015

Hawley, P. and Vaughn, B. (2003). Aggression and adaptive function: The bright side to bad behaviour. Merrill-Palmer Quarterly, 49, 239-242. https://doi.org/10.1353/mpq.2003.0012

Hinduja, S. and Patchin, J. W. (2017). Cultivating youth resilience to prevent bullying and cyberbullying victimization. Child Abuse and Neglect, 73, 51-62. doi:10.1016/j.chiabu.2017.09.010

Hirschtritt, M. E., Ordóñez, A. E., Rico, Y. C. and Lewinn, K. Z. (2015). Internal resilience, peer victimization, and suicidal ideation among adolescents. International Journal of Adolescent Medicine and Health, 27(4), 415-423. doi:10.1515/ijamh-2014-0060

Holt, M. K., Kantor, G. K. and Finkelhor, D. (2009). Parent/child concordance about bullying involvement and family characteristics related to bullying and peer victimization. Journal of School Violence, 42-69.

Juvonen, J. and Graham, S. (2014). Bullying in schools: The power of bullies and the plight of victims. Annual Review

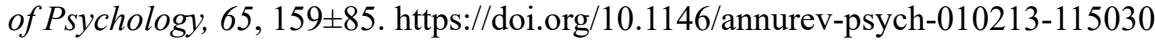

Kochel, K. P., Ladd, G. W. and Rudolph, K. D. (2012). Longitudinal associations among youth depressive symptoms, peer victimization, and low peer acceptance: an interpersonal process perspective. Child Dev., 83, 637-650. doi: 10.1111/j.1467-8624.2011.01722.x 
Matea Belošević, Martina Ferić, Ivana Mitrić: Čimbenici otpornosti i iskustvo vršnjačkog nasilja / Resilience factors and experience of peer...

Košir, K., Klasinc, L., Špes, T., Pivec, T., Cankar, G. and Horvat, M. (2019). Predictors of self-reported and peerreported victimization and bullying behaviour in early adolescents: The role of school, classroom, and individual factors. European Journal of Psychology of Education, 35(2), 381-402. doi:10.1007/s10212-019-00430-y

Laboratorij za prevencijska istraživanja ERF (2019). Projekt pozitivan razvoj adolescenata u Hrvatskoj. Pojedinačni izvještaji za lokalitete: stanje u varaždinskim srednjim školama (internal document).

Lerner, R. M. (2003). Developmental assets and asset-building communities: A view of the issues. In: R. M. Lerner and P. L. Benson (Eds.). Developmental assets and asset-building communities: Implications for research, policy, and practice (str. 3-18). New York: Kluwer Academic/Plenum Press. doi:10.1007/978-1-4615-0091-9_1

Lerner, J.V., Phelps, E., Forman, Y., Bowers, E. P. (2009). Positive youth development. In: L. D. Steinberg and R.M. Lerner (Eds.). Handbook of adolescent psychology (str. 524-558). Hoboken: John Wiley and Sons. doi:10.1002/9780470479193.adlpsy001016

Lerner R. M., Agans, J., Arbeit, M. R., Chase, P. A., Weiner, M. B., Schmid Callina, K. and Alberts Warren, A. E. (2013). Resilience and Positive Youth Development: A Relational Developmental Systems Model. In: Goldstein S. and Brooks R. (Eds.). Handbook of Resilience in Children. Springer, Boston, MA. https://doi.org/10.1007/9781-4614-3661-4_17

Lin, S., Yu, C., Chen, W., Tian, Y. and Zhang, W. (2018). Peer victimization and aggressive behaviour among Chinese adolescents: delinquent peer affiliation as a mediator and parental knowledge as a moderator. Frontiers in Psychology, 9. doi:10.3389/fpsyg.2018.01036

Lippman, L. H., Moore, K. A. and McIntosh, H. (2011). Positive indicators of child well-being: a conceptual framework, measures, and methodological issues. Applied Research in Quality of Life, 6(4), 425-449. doi: 10.1007/s11482011-9138-6

Luthar, S. S. (2006). Resilience in development: A synthesis of research across five decades. In: D. Cicchetti and D. J. Cohen (Eds.). Developmental psychopathology: Risk, disorder, and adaptation (str. 739-795). New York: John Wiley and Sons, Inc. doi:10.1002/9780470939406.ch20

Ma, X. (2002). Bullying in middle school: individual and school characteristics of victims and offenders, school effectiveness and school improvement. Int J Res Policy Pract, 13, 63-89.

Magis, K. (2010). Community Resilience: An Indicator of Social Sustainability, Society and Natural Resources. An International Journal, 23(5), 401-416. doi:10.1080/08941920903305674

Malti, T., Perren, S. and Buchmann, M. (2010). Children's Peer Victimization, Empathy, and Emotional Symptoms. Child Psychiatry and Human Development, 41(1), 98-113. doi:10.1007/s10578-009-0155-8

Masten, A.S. (2014). Global perspectives on resilience in children and youth. Child development, 85(1), 6-20. doi:10.1111/cdev.12205

Masten, A. S. and Barnes, A. J. (2018). Resilience in Children: Developmental Perspectives.Children, 5(7). 98.

Menesini, E., Sanchez, V., Fonzi, A., Ortega, R., Costabile, A. and Lo Feudo, G. (2003). Moral emotions and bullying: a cross-national comparison of differences between bullies, victims and outsiders. Aggressive Behavior, 29, 515-530.

Modecki, K. L., Minchin, J., Harbaugh, A. G., Guerra, N. G. and Runions, K. C. (2014). Bullying prevalence across contexts: A meta-analysis measuring cyber and traditional bullying. Journal of Adolescent Health, 55, 602-611.

Namy, S., Carlson, C., Pala, A. N., Faris, D., Knight, L., Allen, E., Devries, K. and Naker, D. (2017). Gender, violence and resilience among Ugandan adolescents. Child Abuse and Neglect, 70, 303-314. doi:10.1016/j. chiabu.2017.06.015

Nansel, T. R., Overpeck, M., Pilla, R. S., Ruan, W. J., Simons-Morton, B. and Scheidt, P. (2001). Bullying behaviours among US youth: prevalence and association with psychosocial adjustment. Jama, 285(16), 2094-2100. https:// doi.org/10.1001/jama.285.16.2094

Nearchou, F. A., Stogiannidou, A., Kiosseoglou, G. (2014). Adaptation and psychometric evaluation of a resilience measure in Greek elementary school students. Psychology in the Schools, 51(1), 58-71. doi:10.1002/pits.21732 
Novak, M., Ferić, M., Kranželić, V. and Mihić, J. (2019). Konceptualni pristupi pozitivnom razvoju adolescenata. Ljetopis socijalnog rada, 26(2), 155-184. https://doi.org/10.3935/ljsr.v26i2.294

Obradovic-Tomasevic, B., Santric-Milicevic, M., Vasic, V., Vukovic, D., Sipetic-Grujicic, S., Bjegovic-Mikanovic, V., Terzic-Supic, Z., Tomasevic, R. and Babic, U. (2019). Prevalence and predictors of violence victimization and violent behaviour among youths: A Population-based study in Serbia. International Journal of Environmental Research and Public Health, 16(17), 3203. doi:10.3390/ijerph16173203

Olweus, D. (1993). Annotation: Bullying at school: Basic facts and effects of a school based intervention program. Journal of Child Psychology and Psychiatry, 35(7), 1171-1190. https://doi.org/10.1111/j.1469-7610.1994.tb01229.x

Paciello, M., Fida, R., Tramontano, C., Lupinetti, C. and Caprara, G. V. (2008). Stability and change of moral disengagement and its impact on aggression and violence in late adolescence. Child Development, 79(5), 12881309. https://doi.org/10.1111/j.1467-8624.2008.01189.x

Parsai, M., Voisine, S., Marsiglia, F.F., Kulis, S., Nieri, T. (2008). The protective and risk effects of parents and peers on substance use, attitudes, and behaviours of Mexican and Mexican American female and male adolescents. Youth and Society, 40(3), 353-376. doi:10.1177/0044118X08318117

Piko, B. F. and Kovács, E. (2010). Do parents and school matter? Protective factors for adolescent substance use. Addictive Behaviors, 35(1), 53-56. doi:10.1016/j.addbeh.2009.08.004

Pituch, K. A. and Stevens, J. (2016). Applied multivariate statistics for the social sciences: Analyses with SAS and IBMS SPSS. New York: Routledge

Rajhvajn Bulat, L. and Ajduković, M. (2012). Obiteljske i psihosocijalne odrednice vršnjačkog nasilja među mladima. Psihologijske teme, 21(1), 167-194.

Reić Ercegovac, I. (2016). Doživljeno vršnjačko nasilje: relacije s dobi, spolom, razrednim ozračjem i školskim uspjehom. Školski vjesnik, 65(2), 251-271.

Rudolph, K. D., Lansford, J. E., Agoston, A. M., Sugimura, N., Schwartz, D., Dodge, K. A. (2014). Peer victimization and social alienation: predicting deviant peer affiliation in middle school. Child Dev. 85, 124-139. doi: 10.1111/ cdev. 12112

Sapouna, M. and Wolke, D. (2013). Resilience to bullying victimization: The role of individual, family and peer characteristics. Child Abuse and Neglect, 37(11), 997-1006. doi:10.1016/j.chiabu.2013.05.009

Shean, M. (2015). Current theories relating to resilience and young people: a literature review. Melbourne: Victorian Health Promotion Foundation.

Sittichai, R. and Smith, P. K. (2015). Bullying in south east asian countries: A review. Aggression and Violent Behavior, $23,22 \pm 35$.

Smith, P. K and Shu S. (2000). What good schools can do about bullying: findings from a survey in English schools after a decade of research and action. Childhood, 7(2), 193-212.

Sofronoff, K., Dark, E. and Stone, V. (2011). Social vulnerability and bullying in children with Asperger syndrome. Autism, 15(3), 355-372.

Stoddard, S. A., Heinze, J. E., Choe, D. E. and Zimmerman, M. A. (2015). Predicting violent behaviour: The role of violence exposure and future educational aspirations during adolescence. Journal of Adolescence, 44, 191-203. doi:10.1016/j.adolescence.2015.07.017

Tobias, S. and Chapanar, T. (2016). Predicting resilience after cyberbully victimization among high school students. Journal of Psychological and Educational Research JPER, 24(1), 7-25.

Tone, E. B. and Tully, E. C. (2014). Empathy as a "risky strength": A multilevel examination of empathy and risk for internalizing disorders. Development and Psychopathology, 26(4pt2), 1547-1565. doi:10.1017/s0954579414001199

Ungar, M. (2011). The social ecology of resilience. Addressing contextual and cultural ambiguity of a nascent construct. American Journal of Orthopsychiatry, 81, 1-17. doi:10.1111/j.1939-0025.2010.01067.x 
Ungar, M., Ghazinour, M., Richter J. (2013). Annual Research Review: What is resilience within the social ecology of human development? Journal of Child Psychology and Psychiatry, 54(4), 348-366. doi:10.1111/jcpp.12025

U.S. DEPARTMENT OF EDUCATION (2019). Student Reports of Bullying: Results From the 2017 School Crime Supplement to the National Crime Victimization Survey. National Center for Education Statistics. Accessed 03. September 2020. on https://nces.ed.gov/pubs2019/2019054.pdf.

Van de Mortel, T. F. (2008). Faking it: Social desirability response bias in self-report research. Australian Journal of Advanced Nursing, 25(4), 40.

Velki, T. and Vrdoljak, G. (2013). Uloga nekih vršnjačkih i školskih varijabli u predviđanju vršnjačkoga nasilnog ponašanja. Društvena istraživanja, 22(1), 101-120. https://doi.org/10.5559/di.22.1.06

Velki, T. (2019). Usporedba prevalencije i predikcije vršnjačkog nasilja sa vršnjačkim zlostavljanjem. Ljetopis socijalnog rada, 26 (3), 363-390. https://doi.org/10.3935/ljsr.v26i3.218

Vlah, N. and Perger, S. (2014). Povezanost vršnjačkog nasilja s percipiranom školskom klimom kod učenika osnovne škole. Kriminologija i socijalna integracija, 22(1), 1-25.

Zimmerman, M. A., Stewart, S. E., Morrel-Samuels, S., Franzen, S. and Reischl, T. M. (2010). Youth Empowerment Solutions for Peaceful Communities: Combining Theory and Practice in a Community-Level Violence Prevention Curriculum. Health promotion practice, 12(3), 425-39. doi: 10.1177/1524839909357316.

Zimmerman, M. A., Stoddard, S. A., Eisman, A. B., Caldwell, C. H., Aiyer, S. M. and Miller, A. (2013). Adolescent resilience: Promotive factors that inform prevention. Child Development Perspectives, 7(4), 215-220. doi:10.1111/ cdep. 12042

Zych, I., Farrington, D. P. and Ttofi, M. M. (2019). Protective factors against bullying and cyberbullying: A systematic review of meta-analyses. Aggression and Violent Behavior, 45, 4-19. https://doi.org/10.1080/15388220.2013.8 44072

Zych, I. and Llorent, V.J. (2019). Affective empathy and moral disengagement related to late adolescent bullying perpetration. Ethics and Behavior, 29, 547-556. https://doi.org/10.1080/10508422.2018.1521282

Zych, I., Viejo, C., Vila, E. and Farrington, D. P. (2019). School bullying and dating violence in adolescents: a systematic review and meta-analysis. Trauma, Violence, and Abuse, Online First. https://doi.org/10.1177/1524838019854460

Youngblade, L. M., Theokas, C., Schulenberg, J., Curry, L., Huang I. C. and Novak, M. (2007). Risk and Promotive Factors in Families, Schools, and Communities: A Contextual Model of Positive Youth Development in Adolescence. Pediatrics, 119 (1), 47-53; doi:10.1542/peds.2006-2089H

World Health Organization (WHO). (2015). Preventing youth violence: an overview of the evidence. Geneva, Switzerland: World Health Organization. https://apps.who.int/iris/handle/10665/181008 